\title{
New particle formation from the oxidation of direct emissions of pine seedlings
}

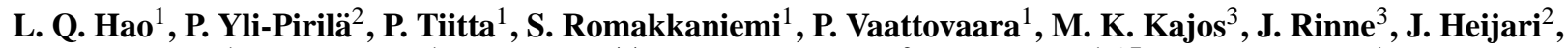 \\ A. Kortelainen ${ }^{1}$, P. Miettinen ${ }^{1}$, J. H. Kroll ${ }^{4}{ }^{*}$, J. K. Holopainen ${ }^{2}$, J. N. Smith ${ }^{1,6,7}$, J. Joutsensaari ${ }^{1}$, M. Kulmala ${ }^{3}$, \\ D. R. Worsnop ${ }^{1,3,4,5}$, and A. Laaksonen ${ }^{1,5}$ \\ ${ }^{1}$ Department of Physics, University of Kuopio, Kuopio, 70211, Finland \\ ${ }^{2}$ Department of Environmental Sciences, University of Kuopio, Kuopio, 70211, Finland \\ ${ }^{3}$ Department of Physics, P.O box 68, University of Helsinki, Helsinki, 00014, Finland \\ ${ }^{4}$ Aerodyne Research, Inc., Billerica, MA 08121-3976, USA \\ ${ }^{5}$ Finnish Meteorological Institute, Helsinki, 00101, Finland \\ ${ }^{6}$ Atmospheric Chemistry Division, National Center for Atmospheric Res., 1850 Table Mesa Dr., Boulder, CO, 80305, USA \\ ${ }^{7}$ Finnish Meteorological Institute, Kuopio, 70211, Finland \\ *now also at: Dept. of Civil and Environmental Engineering, Massachusetts Institute of Technology, Cambridge MA, USA
}

Received: 11 March 2009 - Published in Atmos. Chem. Phys. Discuss.: 27 March 2009

Revised: 26 September 2009 - Accepted: 2 October 2009 - Published: 28 October 2009

\begin{abstract}
Measurements of particle formation following the gas phase oxidation of volatile organic compounds (VOCs) emitted by Scots pine (Pinus sylvestris L.) seedlings are reported. Particle formation and condensational growth both from ozone $\left(\mathrm{O}_{3}\right)$ and hydroxyl radical $(\mathrm{OH})$ initiated oxidation of pine emissions (about 20-120 ppb) were investigated in a smog chamber. During experiments, tetramethylethylene (TME) and 2-butanol were added to control the concentrations of $\mathrm{O}_{3}$ and $\mathrm{OH}$. Particle formation and condensational growth rates were interpreted with a chemical kinetic model. Scots pine emissions mainly included $\alpha$-pinene, $\beta$ pinene, $\Delta^{3}$-carene, limonene, myrcene and $\beta$-phellandrene, composing more than $95 \%$ of total emissions. Modeled $\mathrm{OH}$ concentrations in the $\mathrm{O}_{3}$ - and $\mathrm{OH}$-induced experiments were on the order of $\sim 10^{6}$ molecules $\mathrm{cm}^{-3}$. Our results demonstrate that $\mathrm{OH}$-initiated oxidation of VOCs plays an important role in the nucleation process during the initial new particle formation stage. The highest average particle formation rate of $360 \mathrm{~cm}^{-3} \mathrm{~s}^{-1}$ was observed for the $\mathrm{OH}$-dominated nucleation events and the lowest formation rate of less than $0.5 \mathrm{~cm}^{-3} \mathrm{~s}^{-1}$ was observed for the case with only $\mathrm{O}_{3}$ present as an oxidant. In contrast to the particle formation process, ozonolysis of monoterpenes appears to be much more efficient to the aerosol growth process following nucleation.
\end{abstract}

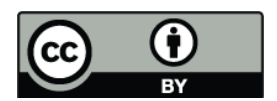

Correspondence to: L. Q. Hao (liqing@uku.fi)
Higher contributions of more oxygenated products to the SOA mass loadings from $\mathrm{OH}$-dominated oxidation systems were found as compared to the ozonolysis systems. Comparison of mass and volume distributions from the aerosol mass spectrometer and differential mobility analyzer yields estimated SOA effective densities of $1.34 \pm 0.06 \mathrm{~g} \mathrm{~cm}^{-3}$ for the $\mathrm{OH}+\mathrm{O}_{3}$ oxidation systems and $1.38 \pm 0.03 \mathrm{~g} \mathrm{~cm}^{-3}$ for the $\mathrm{O}_{3}$ dominated chemistry.

\section{Introduction}

On a worldwide basis, the annual biogenic volatile organic compounds (VOCs) budget is estimated to be in the range of 491 1150 Tg C (Guenther et al., 1995; Griffin et al., 1999). Biogenic VOCs react with $\mathrm{O}_{3}, \mathrm{OH}$ and nitrate radical $\left(\mathrm{NO}_{3}\right)$, leading to the formation of secondary organic aerosols (SOA). Globally, the annual SOA production from these biogenic precursors is estimated to range from 2.5 to $44.5 \mathrm{Tg}$ C (Tsigaridis and Kanakidou, 2003), comprising about $60 \%$ of the organic aerosol mass on the global scale and an even higher fraction regionally (Kanakidou et al., 2005). SOA can directly affect the Earth's radiation budget by scattering and absorbing incoming solar radiation (Kanakidou et al., 2005). Additionally, SOA can indirectly affect the radiation budget by modifying cloud properties through its potential contribution to the population of cloud

Published by Copernicus Publications on behalf of the European Geosciences Union. 


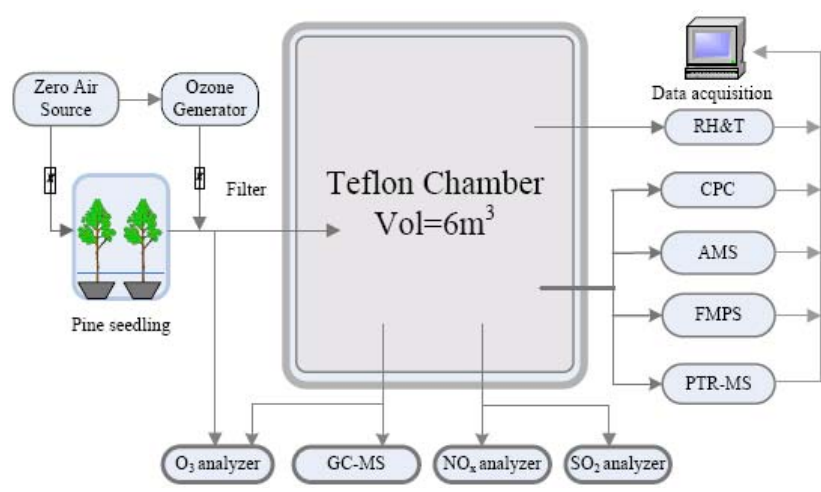

Fig. 1. Experimental schematic system used in these experiments.

condensation nuclei (CCN). SOA may also have adverse effects on human health through their inhalation. Understanding these effects requires a greater knowledge of the mechanisms inducing aerosol formation in the atmosphere.

Monoterpenes and isoprene are important classes of globally emitted organic biogenic species. Their oxidation can lead to low volatility products (low saturation vapor pressure) which are believed to be able to nucleate once their saturation ratio increased sufficiently. Compounds with higher saturation vapor pressure, known as semi-volatile organic compounds, will partition into previously formed particles, contributing to the growth and mass loadings of atmospheric aerosols. Thus, the SOA formation from oxidation of monoterpenes (Hoffmann et al., 1997; Jang and Kamens, 1999; Gao et al., 2004; Shilling et al., 2008; Presto and Donahue, 2005; Odum et al., 1996; Yu et al., 1999) and isoprene (Ng et al., 2007; Kroll et al., 2006; Claeys et al, 2004) by $\mathrm{OH}, \mathrm{O}_{3}$ and $\mathrm{NO}_{3}$ has been intensively studied in laboratory and field campaigns (e.g. Kulmala et al., 2004; Laaksonen et al., 2008). These studies have demonstrated that the atmospheric oxidation of monoterpenes and isoprene represents a significant source of SOA. Despite the important advances in this area, SOA formation in the atmosphere is still poorly understood. For example, the relative roles $\mathrm{OH}$ and $\mathrm{O}_{3}$ play in the SOA formation is still largely unconstrained and results from previous studies are somewhat contradictory. Bonn and Moortgat (2002) and Koch et al. (2000) concluded that $\mathrm{OH}$ oxidation of monoterpenes in the atmosphere is not an important source of new SOA, whereas Burkholder et al. (2007) reported that $\mathrm{OH}$-initiated oxidation allows for new particle formation. Moreover, in most chamber studies, only single organic precursors are traditionally employed as model compounds to simulate SOA formation. Since the mechanisms of SOA formation from oxidation of biogenic hydrocarbons are complex, it is uncertain as to what degree the results from the single monoterpene chamber studies can be extrapolated to the conditions prevailing in the real atmosphere (VanReken et al., 2006). Recent studies have started to address these types of questions. In these studies, aerosol formation events have been simulated in more realistic conditions by using the direct biogenic emissions from macroalgae (McFiggans et al., 2004), white cabbage (Joutsensaari et al., 2005; Pinto et al., 2007), oak and loblolly pine (VanReken et al., 2006), Scots pine (Vaattovaara et al., 2009), birch, pine and spruce (Mentel et al., 2009). In some of these studies, new particle formation efficiencies from $\mathrm{OH}$ - or $\mathrm{O}_{3}$-induced oxidation were also investigated.

Here we presented results from chamber studies of new particle formation using direct VOC emissions of living Scots pine seedlings. Scots pine was selected because it is one of the dominant tree species in the European boreal forest (Räisänen et al., 2008). Both $\mathrm{O}_{3}$ and $\mathrm{OH}$ are used as oxidants in the controlled conditions of these experiments. Our motivation is to evaluate the roles that these oxidants play in the formation of new particles and in the subsequent condensational growth. We also carry out measurements of aerosol chemical composition and densities. By using a mixture of VOCs emitted from plants, rather than a single SOA precursor, we are able to get more realistic and important information on which processes are more important in atmospheric aerosol formation.

\section{Experimental description}

The major components of the experimental system consisted of a biogenic emission enclosure, reaction chamber and both gas-phase and aerosol particle sampling systems. A block diagram of this system is shown in Fig. 1 and the overall system components and analysis methods are described in detail below.

\subsection{Plant materials}

Scots pine seedlings (1 year-old) were obtained from a forest nursery (Finnish Forest Research Institute, Suonenjoki Research Unit, Suonenjoki, Finland) in May and planted in 7.51 plastic pots in 2:1 (v/v) quartz sand $(\varnothing 0.5-1.2 \mathrm{~mm}$, SP Minerals Partek, Finland) and fertilized sphagnum peat (Kekkilä PP6, Finland). After planting, seedlings were grown in an open field site (Research Garden, University of Kuopio) until the end of July. Then the seedlings were taken into a greenhouse to avoid onset of winter dormancy. In October, prior to the experiments, the seedlings were kept in growth chambers (see Vuorinen et al., 2004 for more detail) at a temperature of $+22^{\circ} \mathrm{C}$. To simulate herbivore attack on tree bark and to activate the chemical defense of seedlings, $3 \mathrm{~cm}$ long and $2 \mathrm{~mm}$ deep cuts were made on the base of main stem by a knife. The purpose of pretreatment on the seedlings is to increase the total VOC emissions. After these preparations, two seedlings were selected as the trial plants and placed carefully in two individual transparent Teflon ${ }^{\mathrm{TM}}$ FEP bags. These bags served as manifolds through which clean air passed to transport the pine emissions to the reaction 
Table 1. Initial conditions of chamber experiments performed and analysis results.

\begin{tabular}{|c|c|c|c|c|c|c|c|c|c|c|c|}
\hline \multirow[b]{2}{*}{$\begin{array}{l}\text { Exp. } \\
\text { No. }\end{array}$} & \multirow[b]{2}{*}{$\begin{array}{l}\text { VOCs } \\
\text { initial } \\
(\mathrm{ppb})\end{array}$} & \multirow[b]{2}{*}{$\begin{array}{l}\text { TME } \\
\text { initial } \\
\text { (ppb) }\end{array}$} & \multicolumn{4}{|c|}{ First $\mathrm{O}_{3}$ addition } & \multirow[b]{2}{*}{$\begin{array}{l}\text { Inlet } \\
(\mathrm{ppb})\end{array}$} & \multirow[b]{2}{*}{$\begin{array}{l}\text { Start } \\
\text { time } \\
(\mathrm{min})\end{array}$} & \multirow[b]{2}{*}{$\begin{array}{l}\text { time } \\
(\min )^{*}\end{array}$} & \multicolumn{2}{|c|}{ Second $\mathrm{O}_{3}$ addition } \\
\hline & & & $\begin{array}{l}\text { Inlet } \\
(\mathrm{ppb})\end{array}$ & $\begin{array}{l}\text { time } \\
(\mathrm{min})^{*}\end{array}$ & $\begin{array}{l}\text { Peak } \mathrm{O}_{3} \\
(\mathrm{ppb})^{* *}\end{array}$ & $\begin{array}{l}\text { Peak OH } \\
\text { (molecule } \\
\mathrm{cm}^{-3}, \\
\left.\times 10^{6}\right)^{* * *}\end{array}$ & & & & $\begin{array}{l}\text { Peak } \mathrm{O}_{3} \\
(\mathrm{ppb})^{* *}\end{array}$ & $\begin{array}{l}\text { PeakOH } \\
\text { (molecule } \\
\mathrm{cm}^{-3}, \\
\left.\times 10^{6}\right)^{* * *}\end{array}$ \\
\hline E1a & 74.1 & 118 & 200 & 25 & 4.15 & 1.07 & 200 & 55 & 25 & 15.1 & 1.85 \\
\hline E1b & 28.8 & 342 & 200 & 75 & 5.17 & 1.79 & / & / & / & I & I \\
\hline E1c & 113.8 & 984 & 200 & 75 & $\sim 0$ & $<0.19$ & 800 & 80 & 30 & 17.8 & 3.32 \\
\hline E2 & 23.2 & l & 200 & 13 & 20.7 & 0.33 & / & / & / & / & / \\
\hline E3 & 100.3 & $\begin{array}{l}\text { 2-butanol, } \\
54 \mathrm{ppm}\end{array}$ & 60 & 30 & 6.17 & 0.0036 & 200 & 85 & 30 & 37.4 & 0.012 \\
\hline
\end{tabular}

\footnotetext{
* Duration of ozone addition into the chamber.

** Measured maximum $\mathrm{O}_{3}$ concentration inside the chamber.

*** Modeled maximum $\mathrm{OH}$ concentration inside the chamber.
}

chamber. Six lamps (Lival Shuttle Plus, Lival Oy, Sipoo, Finland, $24 \mathrm{~W}$, PAR ca. $350 \mu \mathrm{mol} \mathrm{m}^{-2} \mathrm{~s}^{-1}$ ) were utilized to ensure the optimal photosynthesis activity and VOC emissions.

\subsection{Reaction chamber experiments}

The reaction chamber for this study is a $6 \mathrm{~m}^{3}$ rectangular chamber made of Teflon ${ }^{\mathrm{TM}}$ FEP film, which is attached to a stainless steel frame. The height of the chamber is $2.5 \mathrm{~m}$ with base dimensions of $1.0 \mathrm{~m} \times 2.4 \mathrm{~m}$. Five experiments were carried out in the present study during 12-26 October 2007. The initial conditions of these experiments are summarized in Table 1. Prior to each experiment, the chamber was continuously flushed overnight with laboratory compressed clean air. The compressed air was processed through activated charcoal, Purafil ${ }^{\mathrm{TM}}$ select and absolute HEPA filter, to remove water, non-methane hydrocarbons, $\mathrm{NO}_{\mathrm{x}}$ and particles. After chamber purification, the air flow was rehumidified by bubbling through distilled water and introduced into the chamber to adjust the chamber relative humidity (RH). Then another additional clean air stream transported pine emissions from the plant enclosure to the chamber through Teflon tubing (approximately $1 \mathrm{~h}$ prior to the start of the experiment). In addition to the plant emissions, in some experiments (e.g. E1a-c), tetramethylethylene (TME; 99+\%, Aldrich) was also added. TME was delivered to the chamber by sending air through a heated bulb containing a known volume of TME. TME was used as a source of hydroxyl radicals $(\mathrm{OH})$. It was chosen because $\mathrm{OH}$ production by TME ozonolysis requires neither $\mathrm{NO}_{\mathrm{x}}$ nor $\mathrm{UV}$ photolysis, and $\mathrm{OH}$ yields are near unity (Lambe et al., 2007; Paulson, et al., 1997). For experiments E2 and E3, no TME was applied. In E3, 2-butanol, used as $\mathrm{OH}$ scavenger, was introduced into the chamber in a similar manner as TME. The concentration of 2-butanol injected was approximately 600 times higher than that of the terpenes so that the reaction rate of $\mathrm{OH}$ with the scavenger exceeded that of $\mathrm{OH}$ with parent hydrocarbons by a factor of 100 (Keywood, et al., 2004; Docherty et al., 2003; Ziemann et al., 2003). Major products of the $\mathrm{OH}+2$-butanol reaction are 2-butanone (with yield of $69 \%$ at room temperature) and acetone (with yield range from 12-29\%) (Aschmann et al., 2002; Jiménez et al., 2005), which have high vapor pressures suggesting that they are too volatile to partition into the particle phase. After the terpenes, TME and 2-butanol were added and given time for mixing, $\mathrm{O}_{3}$ were introduced to initiate oxidation. Ozone was generated by a UV lamp $\mathrm{O}_{3}$ generator. Ozone enriched air (60-800 ppb) was introduced into the chamber (at $40 \mathrm{~L} / \mathrm{min}$ ). In three experiments, two ozone injections were made in order to investigate the roles of oxidants in the new particle growth process, as well as to obtain larger particle sizes and higher aerosol mass loading. The beginning of the first ozone injection marks the start of each experiment. In all experiments, temperature was controlled in the range of $25 \pm 2^{\circ} \mathrm{C}$ and RH in $35 \pm 5 \%$. No seed aerosols were added and the chamber was kept dark with a black polyethylene covering.

Three types of experiments were conducted. In experiments E1a-E1c, TME was added to investigate the role of $\mathrm{OH}$-initiated oxidation in new particle formation. In experiment E2, No TME was added in order to simulate lower $\mathrm{OH}$ conditions. Experiment E3 was performed in the presence of 2-butanol (the $\mathrm{OH}$ scavenger) to investigate the role of ozonolysis alone in new particle formation.

\subsection{Analytical methods and instrumentation}

Nitric oxide (NO), total $\mathrm{NO}_{\mathrm{x}}$ and $\mathrm{SO}_{2}$ concentration inside the chamber were measured with an $\mathrm{AC} 30 \mathrm{M} \mathrm{NO}_{\mathrm{x}}$ analyzer and $\mathrm{AF} 21 \mathrm{M} \mathrm{SO}_{2}$ analyzer (Environment s.a.), respectively. $\mathrm{O}_{3}$ concentration was monitored at the inlet and inside the chamber by two DASIBI 1008-RS $\mathrm{O}_{3}$ analyzers (Dasibi Environmental Corporation, Glendale, CA, USA). Temperature and $\mathrm{RH}$ were measured continuously using a $\mathrm{RH}$ and 
temperature transmitter (Vaisala Humitter Y50). In all the experiments, $\mathrm{SO}_{2}$ concentration was lower than the detection limit of analyzer $(\sim 1 \mathrm{ppb})$.

Measurements of VOC emissions from pine seedlings were made using two instruments, a gas chromatographymass spectrometer (GC-MS, Hewlett-Packard GC model 6890, MSD 5973) and a proton transfer reaction mass spectrometer (PTR-MS, Ionicon Analytik GmbH). For off-line analysis, VOCs were sampled onto about $150 \mathrm{mg}$ Tenax TA adsorbent (Supelco, mesh 60/80) for 15 or $30 \mathrm{~min}$. The collected VOCs were then analyzed with GC-MS. Identification of the compounds was based on the retention time and comparison of mass spectra with those of pure standards. The analysis method used here has been described in detail elsewhere (Pinto et al., 2007; Joutsensaari et al., 2005; Vuorinen et al., 2004). PTR-MS was used for the continuous on-line measurements of concentrations of selected parent hydrocarbons and various gas-phase intermediates and products. A detailed description of PTR-MS technique is given by Lindinger et al. (1998) and de Gouw and Warneke (2007). The calibration procedure and mixing ratio calculations were described in Taipale et al. (2008). During every experiment full scan mode was used to see if there were important compounds other than the selected ones that were measured continuously. Selected ions monitored were those with mass-to-charge $(\mathrm{m} / \mathrm{z})$ consistent with formaldehyde $(\mathrm{m} / \mathrm{z}$ $30+1)$, methanol $(\mathrm{m} / \mathrm{z} 32+1)$, acetone $(\mathrm{m} / \mathrm{z} 58+1)$, isoprene $(\mathrm{m} / \mathrm{z} 68+1)$, TME $(\mathrm{m} / \mathrm{z} 84+1)$, monoterpenes $(\mathrm{m} / \mathrm{z} 136+1)$ and sesquiterpenes $(m / z 204+1)$.

Aerosol chemical composition and mass size distributions were measured by an Aerodyne Aerosol Mass Spectrometer (AMS). Detailed descriptions of the AMS measurements, calibration, modes of operation and data processing can be found in other publications (Jayne et al., 2000; Allan et al., 2003, 2004; Jimenez et al., 2003a, 2003b; Zhang et al., 2004). Briefly, the AMS uses an aerodynamic lens to focus particles into a tight beam that is introduced into a high vacuum detection region $\left(10^{-8}\right.$ Torr). Particles are detected by flash-vaporization on a porous tungsten surface heated to $600^{\circ} \mathrm{C}$, followed by ionization by a $70 \mathrm{eV}$ electron source. The resulting positive ion fragments are detected by a Quadrupole Mass Spectrometer (QMA 430, Balzers Instruments, Balzers, Liechtenstein). Particle size is calculated from the particle time of flight. Mass spectra are achieved by the difference between sample and background and ion signals.

Aerosol particle size distributions over a range of 5.6$560 \mathrm{~nm}$ were measured using a fast mobility particle sizer spectrometer (FMPS, TSI model 3091). The FMPS was operated with aerosol and sheath flows of 10 and $40 \mathrm{Lmin}^{-1}$, respectively. The high measurement resolution (sampling in $1 \mathrm{~s}$ resolution and averaged in 5 min resolution in this study) enables the visualization of particle size distributions during new particle formation events.

\subsection{Calculating particle formation and growth rates}

Particles in the sub- $25 \mathrm{~nm}$ size range are considered newly formed particles from precursor vapors (Dal Maso et al., 2005). Thus, in this work the particle formation rate was derived from the rate of change of the number concentration of aerosols with diameters between $5.6 \mathrm{~nm}$ (the lower size limit of the FMPS) and $20 \mathrm{~nm}$. At the onset of new particle formation this formation rate is equal to the instantaneous particle formation rate at $\sim 6 \mathrm{~nm}\left(\mathrm{~J}_{6}\right)$, which can be related to the nucleation rate using various modeling approaches (Weber et al., 1997; Kerminen and Kulmala, 2002; Lehtinen et al., 2007). One means of assessing the relationship between the nucleation rate and $\mathrm{J}_{6}$ is to calculate the factor $\eta$ (Kerminen and Kulmala, 2002):

$\eta=\frac{\gamma C S^{\prime}}{G R}$

where $\gamma$ is a proportionality factor that is approximately equal to $0.2 \mathrm{~nm}^{2} \mathrm{~m}^{2} \mathrm{hr}^{-1}, C S_{\alpha=1}^{\prime}$ is the flux of non-volatile vapors to the pre-existing particle population in $\mathrm{m}^{-2}$, and $G R$ is the observed growth rate in $\mathrm{nm} \mathrm{hr}^{-1} . \eta$ is conceptually similar to the "L-parameter" of McMurry et al. (2005), since the numerator represents the rate at which the critical cluster coagulates with the pre-existing particle population and the denominator the rate at which it grows by condensation. In the limit that $\eta \ll 1$ then growth rates of clusters greatly exceed loss of the clusters to coagulation, and thus the observed particle formation rate is an adequate representation of the nucleation rate. Using the measured average growth rates shown in Fig. 5, and adding the assumption that wall losses are negligible over the timescales of the growth of the nuclei from the critical cluster (ca. $1 \mathrm{~nm}$ in diameter) to $6 \mathrm{~nm}$ in diameter, we estimate this ratio to lie in the range of 0.1 to 0.001 , where 0.1 corresponds to slower growth rates observed with E1c. Thus for the higher growth rates such as those observed during E1a, we expect the particle formation rates plotted in Fig. 5 to be approximately equal to the nucleation rate. For the growth rate calculations presented below, the geometric mean diameters (GMD) from the FMPS measurements were adopted to estimate the condensational growth rates of new particles.

\subsection{Effective density}

AMS measures the vacuum aerodynamic diameter $\left(D_{v a}\right)$, defined as the diameter of a standard density $\left(\rho_{0}\right)$ sphere with the same terminal velocity as the particle of interest in a free molecular regime. The FMPS, on the other hand, provides a measurement of the mobility diameter $\left(D_{m}\right)$, the diameter of a sphere with the identical migration velocity of particle in a constant electric field at atmospheric pressure. The effective density of particle, $\rho_{\text {eff., }}$, is defined as ratio of the vacuum aerodynamic and mobility diameter multiplied by unit 
Table 2. Gas phase kinetic constants, $\mathrm{OH}$ yield $\left(\mathrm{Y}_{\mathrm{OH}}\right)$, acetone $(\mathrm{AT})$ yield $\left(\mathrm{Y}_{\mathrm{AT}}\right)$, formaldehyde $(\mathrm{FAH})$ yield $\left(\mathrm{Y}_{\mathrm{FAH}}\right)$ and correction factors used in the study.

\begin{tabular}{|c|c|c|c|c|c|c|}
\hline \multirow[b]{2}{*}{ VOCs } & \multirow[b]{2}{*}{$\begin{array}{l}\text { Rate constant, } k \\
\left(\mathrm{~cm}^{3} \text { molecule }{ }^{-1} \mathrm{~s}^{-1}\right)^{\mathrm{a}}\end{array}$} & \multirow[b]{2}{*}{$\begin{array}{l}\mathrm{Y}_{\mathrm{OH}} \\
\left(\omega_{i}, \omega_{i}^{\prime}\right)^{\mathrm{a}, \mathrm{b}}\end{array}$} & \multirow[b]{2}{*}{$\begin{array}{l}\mathrm{Y}_{\mathrm{AT}} \\
\left(\beta_{i}, \beta_{i}^{\prime}\right)^{\mathrm{c}, \mathrm{d}}\end{array}$} & \multirow[b]{2}{*}{$\begin{array}{l}\mathrm{Y}_{\mathrm{FAH}} \\
\left(\alpha_{i}, \alpha_{i}^{\prime}\right)^{\mathrm{c}, \mathrm{e}}\end{array}$} & \multicolumn{2}{|c|}{ Correction factor } \\
\hline & & & & & $\left(\gamma, \gamma^{\prime}\right)$ & $\left(\gamma^{\prime \prime}, \gamma^{\prime \prime \prime}\right)$ \\
\hline $\mathrm{TME}+\mathrm{O}_{3}$ & $113 \times 10^{-17}$ & 1.0 & 1.05 & 0.28 & 1.0 & - \\
\hline $\mathrm{TME}+\mathrm{OH}$ & $110 \times 10^{-12}$ & - & 1.7 & - & - & 1.0 \\
\hline Isoprene $+\mathrm{O}_{3}$ & $1.27 \times 10^{-17}$ & 0.27 & - & 0.9 & 1.1 & - \\
\hline Isoprene+OH & $100 \times 10^{-12}$ & - & - & 0.63 & - & 1.2 \\
\hline Myrcene+O 3 & $47 \times 10^{-17}$ & 0.63 & 0.26 & 0.26 & 1.2 & - \\
\hline Mycrene+OH & $215 \times 10^{-12}$ & - & 0.45 & 0.30 & - & 1.3 \\
\hline$\beta$-phellandrene $+\mathrm{O}_{3}$ & $4.7 \times 10^{-17}$ & 0.14 & - & - & 1.1 & - \\
\hline$\beta$-phellandrene $+\mathrm{OH}$ & $168 \times 10^{-12}$ & - & - & - & - & 1.2 \\
\hline Limonene $+\mathrm{O}_{3}$ & $21 \times 10^{-17}$ & 0.67 & 0.02 & 0.02 & 1.1 & - \\
\hline Limonene+OH & $164 \times 10^{-12}$ & - & 0.03 & - & - & 1.2 \\
\hline$\Delta^{3}$-carene $+\mathrm{O}_{3}$ & $3.7 \times 10^{-17}$ & 0.86 & 0.22 & 0.16 & 1.0 & - \\
\hline$\Delta^{3}$-carene+OH & $88 \times 10^{-12}$ & - & 0.15 & 0.21 & - & 1.1 \\
\hline$\alpha$-pinene $+\mathrm{O}_{3}$ & $8.4 \times 10^{-17}$ & 0.8 & 0.08 & 0.15 & 1.0 & - \\
\hline$\alpha$-pinene $+\mathrm{OH}$ & $52.3 \times 10^{-12}$ & - & 0.15 & 0.19 & - & 1.1 \\
\hline$\beta$-pinene $+\mathrm{O}_{3}$ & $1.5 \times 10^{-17}$ & 0.35 & 0.04 & 0.65 & 1.0 & - \\
\hline$\beta$-pinene $+\mathrm{OH}$ & $74.3 \times 10^{-12}$ & - & 0.13 & 0.45 & - & 1.1 \\
\hline Camphene $+\mathrm{O}_{3}$ & $0.09 \times 10^{-17}$ & 0.18 & - & - & 1.0 & - \\
\hline Camphene+OH & $52 \times 10^{-12}$ & - & 0.39 & - & - & 1.1 \\
\hline Sabinene+ $\mathrm{O}_{3}$ & $8.3 \times 10^{-17}$ & 0.33 & 0.03 & - & 1.0 & - \\
\hline Sabinene+OH & $117 \times 10^{-12}$ & - & 0.19 & - & - & 1.2 \\
\hline Terpinolene $+\mathrm{O}_{3}$ & $190 \times 10^{-17}$ & 1.0 & fo & - & 1.1 & - \\
\hline Terpinolene+OH & $225 \times 10^{-12}$ & - & 0.39 & 0.29 & - & 1.2 \\
\hline Acetone+OH & $0.17 \times 10^{-12}$ & - & - & - & - & 1.0 \\
\hline Formaldehyde $+\mathrm{OH}$ & $9.37 \times 10^{-12}$ & - & - & - & - & 1.0 \\
\hline 2-butanol+OH & $8.7 \times 10^{-12}$ & - & - & - & - & 1.0 \\
\hline
\end{tabular}

a Atkinson and Arey (2003a)

b Aschmann et al. (2002); Lambe et al. (2007); Paulson et al. (1997)

c Atkinson and Arey (2003b)

d Tuazon et al. (1998)

e Grosjean et al. (1996)

density (Jimenez et al., 2003b; DeCarlo et al., 2004; Bahreini et al., 2005).

$\rho_{\text {eff. }}=\rho_{0} \frac{D_{v a}}{D_{m}}=\rho_{p} \frac{D_{v e}}{X_{v e} D_{m}}$

where $\rho_{p}$ is the material density, $\rho_{o}$ is the unit density $\left(1 \mathrm{~g} \mathrm{~cm}^{-3}\right), D_{v e}$ is the diameter of a spherical particle having the same volume as the particle under consideration, and $X_{v e}$ is the dynamic shape factor in the free molecular regime.

For spherical particles, the effective density is equivalent to the particle density, while the effective density can be significantly different for a particle with an irregular shape. Note that various definitions of effective density are used in the literature. These definitions do not yield the same numerical values for irregular particles (DeCarlo et al., 2004). In this study, a series of mobility diameters measured by FMPS was compared to their corresponding vacuum aerodynamic diameters measured by AMS in parallel in order to determine the densities of SOA.

\subsection{Modeling of VOC oxidation}

Since new particle formation is initiated by the gas-phase oxidation of VOCs, a kinetic model of VOC oxidation by $\mathrm{O}_{3}$ and $\mathrm{OH}$ was built to interpret the new particle formation and growth events from the perspective of gas-phase chemistry. In this model, the oxidation of VOCs was calculated using the initial measured concentrations of VOCs and known reaction rates. $\mathrm{O}_{3}$ and $\mathrm{OH}$ initiate the oxidation reactions of VOCs and TME and secondary loss process of $\mathrm{OH}$ and $\mathrm{O}_{3}$ are taken into account. Briefly, $\mathrm{O}_{3}$ - and $\mathrm{OH}$-initiated oxidations of these VOCs produce condensing and nucleating 
species, $\mathrm{OH}$ radicals and other volatile compounds:

$\mathrm{VOC}_{i}+\mathrm{O}_{3} \stackrel{k_{\mathrm{O}_{3}}}{\longrightarrow} \mathrm{OH}$ radical + volatile + semivolatile + nonvolatile species

$\mathrm{VOC}_{i}+\mathrm{OH} \stackrel{k_{\mathrm{OH}}^{\mathrm{VOC}_{i}}}{\longrightarrow}$ volatile + semivolatile + nonvolatile species

If TME is present, its ozonolysis leads to the production of $\mathrm{OH}$ radicals:

$\mathrm{TME}+\mathrm{O}_{3} \stackrel{k_{\mathrm{O}_{3}}^{\mathrm{TME}}}{\longrightarrow} \mathrm{OH}+$ other products

Thus, from rates of Eqs. (4) and (5), the formation rate of $\mathrm{OH}$ radical $\left(f_{\mathrm{OH}}\right)$ can be calculated using the following equation:

$$
\begin{aligned}
f_{\mathrm{OH}}= & \omega_{i} k_{\mathrm{O}_{3}}^{\mathrm{TME}}[\mathrm{TME}]\left[\mathrm{O}_{3}\right]+\omega_{\text {isoprene }}^{\prime} k_{\mathrm{O}_{3}}^{\text {isoprene }} \\
& {[\text { isoprene }]\left[\mathrm{O}_{3}\right]+\sum_{i} \omega_{i}^{\prime} k_{\mathrm{O}_{3}}^{\mathrm{MT}_{i}}[\mathrm{MT}]_{i}\left[\mathrm{O}_{3}\right] }
\end{aligned}
$$

where MT represents monoterpenes as listed in Table 2, $\omega_{i}$ and $\omega_{i}^{\prime}$ denote the yields of hydroxyl radicals from the $\mathrm{O}_{3}$ reactions, and $k$ represents rate constants.

Due to the high reaction rate constant of ozone with TME, there is competition of $\mathrm{O}_{3}$ between TME and monoterpenes during the initial stage of reaction. The average consumption rate of $\mathrm{O}_{3}$ can expressed as:

$$
\begin{aligned}
\frac{d\left[\mathrm{O}_{3}\right]}{d t}= & \frac{d\left[\mathrm{O}_{3}\right]_{\text {inlet }}}{d t}-\gamma k_{\mathrm{O}_{3}}^{\mathrm{TME}}[\mathrm{TME}]\left[\mathrm{O}_{3}\right] \\
& -\gamma_{\text {isoprene }}^{\prime} k_{\mathrm{O}_{3}}^{\text {isoprene }}[\text { isoprene }]\left[\mathrm{O}_{3}\right] \\
& -\sum_{i} \gamma_{i}^{\prime} k_{O_{3}}^{\mathrm{MT}_{i}}[\mathrm{MT}]_{i}\left[\mathrm{O}_{3}\right]
\end{aligned}
$$

where $\gamma$ and $\gamma^{\prime}$ are the correction factors to take into account the secondary loss of ozone with products. These correction factors were estimated according to the VOC molecular structures and the complexities of their reactions with $\mathrm{O}_{3}$ and $\mathrm{OH}$ and further confirmed by a model sensitivity test. For the $\mathrm{O}_{3}$-induced oxidation, the correction factors were estimated to be 1.0 ( $\mathrm{Ng}$ et al., 2006), 1.1 and 1.2 for the monoterpenes with one, two and three double $\mathrm{C}=\mathrm{C}$ bonds, respectively. Similarly, for the $\mathrm{OH}$ - initiated oxidation, due to the high reaction activity of $\mathrm{OH}$ with hydrocarbon compounds, the correction factors are estimated to be higher than the $\mathrm{O}_{3}$ oxidation case, with $1.1,1.2$ and 1.3 for those compounds with one, two and three double $\mathrm{C}=\mathrm{C}$ bonds, respectively.

The added TME also resulted in $\mathrm{OH}$ loss due to the high reaction potential of $\mathrm{OH}+\mathrm{TME}$ :

$\mathrm{TME}+\mathrm{OH} \stackrel{k_{\mathrm{OH}}^{\mathrm{TM}}}{\longrightarrow}$ products
Thus reactions $(2-5,7)$ give the time-dependent $\mathrm{OH}$ concentration as:

$$
\begin{aligned}
\frac{d[\mathrm{OH}]}{d t}= & f_{\mathrm{OH}}-\gamma^{\prime \prime} k_{\mathrm{OH}}^{\mathrm{TME}}[\mathrm{TME}][\mathrm{OH}] \\
& -\gamma_{\text {isoprene }}^{\prime \prime \prime} k_{\mathrm{OH}}^{\text {isoprene }}[\text { isoprene }][\mathrm{OH}] \\
& -\sum_{i} \gamma_{i}^{\prime \prime \prime} k_{\mathrm{OH}}^{\mathrm{MT}_{i}}[\mathrm{MT}]_{i}[\mathrm{OH}]
\end{aligned}
$$

where $\gamma^{\prime \prime}$ and $\gamma^{\prime \prime \prime}$ are the correction factors to take into account the secondary loss of $\mathrm{OH}$ by reaction with products. Values of all parameters used in the model are listed in Table 2 .

Products from the $\mathrm{O}_{3}$ - and $\mathrm{OH}$-initiated TME oxidation are formaldehyde, methanol and acetone as well as some minor compounds (Niki et al., 1987; Tuazon et al., 1997, 1998). The vapor pressures of these species are too high to take part into aerosol nucleation and growth processes and so are omitted from the model. Berndt et al. (2004) have also shown that ozonolysis of TME in the absence of $\mathrm{SO}_{2}$ leads to no observable new particle formation. Thus, in this paper, $\mathrm{O}_{3}$ and $\mathrm{OH}$ oxidation rates (excluding the contributions from TME) with VOCs are defined as (hereafter referred to as $\mathrm{O}_{3}$ and $\mathrm{OH}$ rates):

$r_{\mathrm{O}_{3}}=k_{\mathrm{O}_{3}}^{\text {isoprene }}[$ isoprene $]\left[\mathrm{O}_{3}\right]+\sum_{i} k_{\mathrm{O}_{3}}^{\mathrm{MT}_{i}}[\mathrm{MT}]_{i}\left[\mathrm{O}_{3}\right]$

$r_{\mathrm{OH}}=k_{\mathrm{OH}}^{\text {isoprene }}[$ isoprene $][\mathrm{OH}]+\sum_{i} k_{\mathrm{OH}}^{\mathrm{MT}_{i}}[\mathrm{MT}]_{i}[\mathrm{OH}]$

New particle formation rate and growth rate can be constrained directly by the oxidation rates of VOCs:

$F \propto r_{\mathrm{O}_{3}}+r_{\mathrm{OH}}$

$G \propto r_{\mathrm{O}_{3}}+r_{\mathrm{OH}}$

Similarly, for the loss of other compounds and formation of products, the kinetics are described using the following rate equations:

$$
\begin{aligned}
\frac{d[\mathrm{VOC}]_{i}}{d t}= & -k_{\mathrm{O}_{3}}^{\mathrm{VOC}_{i}}[\mathrm{VOC}]_{i}\left[\mathrm{O}_{3}\right] \\
& -k_{\mathrm{OH}}^{\mathrm{VOC}_{i}}[\mathrm{VOC}]_{i}[\mathrm{OH}] \\
\frac{d[\mathrm{TME}]}{d t}= & -k_{\mathrm{O}_{3}}^{\mathrm{TME}}[\mathrm{TME}]\left[\mathrm{O}_{3}\right] \\
& -k_{\mathrm{OH}}^{\mathrm{TME}}[\mathrm{TME}][\mathrm{OH}] \\
\frac{d[\mathrm{AT}]}{d t}= & \sum_{i} \beta_{i} k_{\mathrm{O}_{3}}^{\mathrm{VOC}_{i}}[\mathrm{VOC}]_{i}\left[\mathrm{O}_{3}\right] \\
+ & \sum_{i} \beta_{i}^{\prime} k_{\mathrm{OH}}^{\mathrm{VOC}_{i}}[\mathrm{VOC}]_{i}[\mathrm{OH}] \\
& -k_{\mathrm{OH}}^{\mathrm{AT}}[\mathrm{AT}][\mathrm{OH}]
\end{aligned}
$$




$$
\begin{aligned}
\frac{d[\mathrm{FAH}]}{d t}= & \sum_{i} \alpha_{i} k_{\mathrm{O}_{3}}^{\mathrm{VOC}_{i}}[\mathrm{VOC}]_{i}\left[\mathrm{O}_{3}\right] \\
& +\sum_{i} \alpha_{i}^{\prime} k_{\mathrm{OH}}^{\mathrm{VOC}_{i}}[\mathrm{VOC}]_{i}[\mathrm{OH}] \\
& -k_{\mathrm{OH}}^{\mathrm{FAH}}[\mathrm{FAH}][\mathrm{OH}]
\end{aligned}
$$

where $\beta_{i}, \beta_{i}^{\prime}$ are the yields of acetone (AT) from reactions of $\mathrm{O}_{3}$ and $\mathrm{OH}$ with VOCs and TME. Similarly, $\alpha_{i}$ and $\alpha_{i}^{\prime}$ are the formaldehyde $(\mathrm{FAH})$ yields. $\mathrm{VOC}_{i}$ includes all the monoterpenes, isoprene and TME listed in Table 2.

\section{Results and discussion}

\subsection{Gas-phase chemistry}

\subsubsection{Scots pine emissions}

The observed VOCs emitted from the Scots pine seedlings included monoterpenes, sum of isoprene and 2-methyl-3buten-2-ol (MBO), and minor amounts of other small molecular compounds, e.g. methanol, with monoterpenes dominating the total emissions in this work. Measured monoterpenes included $\alpha$-pinene, $\beta$-pinene, $\Delta^{3}$-carene, $\beta$-phellandrene, limonene and myrcene, making up more than $95 \%$ of the total VOC emissions as tabulated in Table 3. In E1c and E3, there was no detectable $\Delta^{3}$-carene, with E1c exhibiting a very high contribution of $\beta$-pinene to total VOC emissions. The variations in relative emissions of species, specially $\alpha$-pinene, $\beta$-phellandrene, limonene, and $\Delta^{3}$-carene, may be due to emission rates that were sensitive to ambient environmental conditions (Räisänen et al., 2008, Tarvainen et al., 2005) and the frequency of $\Delta^{3}$-carene-rich genotype (Manninen et al., 1998). Field results in Finnish forests have demonstrated the dependence of monoterpene emission rates on environmental temperature and light intensity (Räisänen et al., 2008; Tarvainen et al., 2005). In all cases, sesquiterpenes in the emitted compounds were lower than $0.05 \mathrm{ppb}$ as determined with PTR-MS measurements. This is consistent with observations in Hyytiällä forest in Finland that sesquiterpene emissions from Scots pine are only $2-5 \%$ of the total monoterpene emission rates, with emissions ceasing in September (Tarvainen et al., 2005).

According to the measurements made in two locations in Finland, the major emitted compounds from Scots pine are $\alpha$-pinene, $\beta$-pinene and $\Delta^{3}$-carene, with approximate contributions of $60-85 \%$ to the total observed monoterpene emission rates, although late in autumn $\beta$-phellandrene can make $20 \%$ of total monoterpene emission (Räisänen et al., 2008). Lindfors and Laurila (2000) estimated that total biogenic VOC emissions from Finnish forest are dominated by monoterpenes, which contribute approximately $45 \%$, while in deciduous trees the percentage can be as low as 1015\% (Mäntylä et al., 2008), and isoprene emissions are
Table 3. Percentage molar contributions of different chemical compounds to pine emissions.

\begin{tabular}{llllll}
\hline PineVOCs (\%) & E1a & E1b & E1c & E2 & E3 \\
\hline$\alpha$-pinene & 26.3 & 27.1 & 30.4 & 26.7 & 47.4 \\
$\beta$-pinene & 1.5 & 3.4 & 28.4 & 3.4 & 7.6 \\
Myrcene & 11.9 & 11.8 & 8.8 & 16.4 & 4.6 \\
$\beta$-phellandrene & 8.0 & 16.7 & 4.5 & 20.2 & 4.4 \\
Limonene & 4.5 & 3.5 & 25.8 & 3.4 & 33.2 \\
$\Delta^{3}$-carene & 40.4 & 30.9 & 0 & 22.0 & 0 \\
Camphene & 0.7 & 0.3 & 0.6 & 0.4 & 0.7 \\
Sabinene & 1.8 & 2.4 & 0 & 1.7 & 0 \\
Terpinolene & 1.8 & 1.7 & 0 & 1.7 & 0 \\
Isoprene/MBO & 3.0 & 2.1 & 1.3 & 3.9 & 2.0 \\
Others & 0.1 & 0.1 & 0.2 & 0.2 & 0.1 \\
\hline
\end{tabular}

only $7 \%$ of the annual total. In the USA the main biogenic monoterpene emissions are $\alpha$-pinene, $\beta$-pinene, and limonene (Sakulyanontvittaya et al., 2008). Thus the emission spectrum in this study is very consistent with natural Scots pine and the monoterpene distributions in Europe and USA, making this work more representative of the atmospheric reaction conditions than studies involving single VOCs or mixtures of a few VOCs commonly used in chamber experiments.

\subsection{2 $\mathrm{OH}$ and $\mathrm{O}_{3}$ concentrations inside chamber}

As discussed in Sect. 2.6, the ozonolysis of VOCs leads to the formation of $\mathrm{OH}$ radicals. The modeled peak $\mathrm{OH}$ concentration in this study ranged from $0.3 \times 10^{6}$ (E2, no TME) to $3.32 \times 10^{6}$ molecules $\mathrm{cm}^{-3}$ (E1a-1c, TME). This matches the noon time $\mathrm{OH}$ concentration of $(0.3$ $0.6) \times 10^{6}$ molecules $\mathrm{cm}^{-3}$ in Scots pine (Pinus Sylvestris L.) dominated forests in Finland (Petäjä et al., 2009) and the peak daytime concentration of $(2-10) \times 10^{6}$ molecules $\mathrm{cm}^{-3}$ on the ground level in northern hemisphere during $\mathrm{Au}$ gust/September periods (Atkinson et al., 2000, and references cited therein). $\mathrm{O}_{3}$ concentrations varied from $\sim 4 \mathrm{ppb}$ to $\sim 37.4 \mathrm{ppb}$, which is also consistent with typical ozone mixing ratios measured in remote regions sites (Logan et al., 1985; Guicherit and Roemer, 2000).

\subsubsection{Reaction of emitted VOCs}

Figure 2 shows the decay profiles of the ten VOCs (panel A) tabulated in Table 3 and the formation curves of gasphase acetone and formaldehyde as functions of time (panel B) shown for experiment E1a. The modeled concentrations were calculated based on the $\mathrm{OH}$ - and $\mathrm{O}_{3}$-induced chemistry of these VOCs as described in Sect. 2.6. Possible formation sources of acetone and formaldehyde include $\mathrm{O}_{3}$ and $\mathrm{OH}$-induced chemisty of TME and emitted VOCs as shown in Eq. (16) and (17). Measured concentrations of 

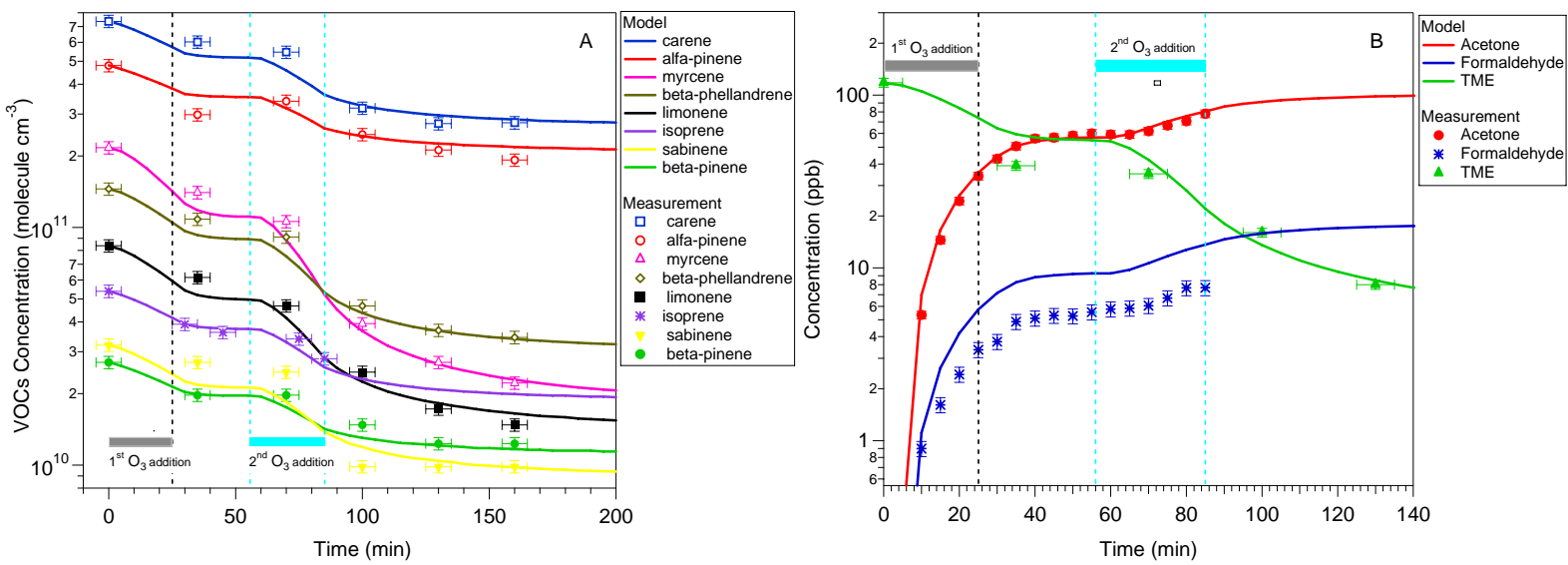

Fig. 2. Comparisions of measured and modeled results from experiment E1a: (a) Changes in emitted VOC concentration upon reaction (from GC-MS measurements) (b) TME decay profiles (from GC-MS measurements) and gas-phase product concentration of acetone and formaldehyde (from PTR-MS measurements). Results from other four experiments are similar and so are not shown here.

parent precusors are very consistent with the modeled results. Measured and modeled acetone concentrations also agree extremely very well, though the modeled formaldehyde concentrations are $10-40 \%$ higher than the measurements, which suggests that formaldehyde formation yields might be somewhat too high. Good agreement between modeled and measured VOC and product concentrations provides further confirmation to the validity of the model used in this study.

\subsection{Formation of new particles}

\subsubsection{New particle formation from $\mathrm{OH}$ - and ozone- induced chemistry}

As the emissions of pine seedlings were oxidized by $\mathrm{O}_{3}$ and $\mathrm{OH}$, various products with differing volatilities were formed. Homogeneous nucleation can occur when the non-volatile products exceed their saturation vapor pressure. Later on, the semi-volatile species begin condensing on the surface of the pre-formed particles, causing an increase in particle size and aerosol volume concentrations. Contour plots of aerosol particle number size distributions and graphs of total number and volume concentrations as well as gas-phase oxidant concentrations are shown in Fig. 3. In these systems, $\mathrm{OH}$ radicals are produced not only by the ozonolysis of TME but also by the ozonolysis of monoterpenes. Both the $\mathrm{OH}$ and $\mathrm{O}_{3}$-initiated oxidation of monoterpenes might contribute to new particle formation. At high concentration of TME, ozonolysis of TME was expected to produce large amounts of $\mathrm{OH}$ radicals based on Eq. (5). It can be seen that a rapid increases in the particle number concentration occurred and obvious new particle formation events took place after the first addition of ozone in all cases. However, the maximum number concentration was 27700 particle $\mathrm{cm}^{-3}$ in the highest TME experiment (E1c), which was much lower than the
128000 particle $\mathrm{cm}^{-3}$ in the lowest TME case (E1a). This is caused by the higher $\mathrm{OH}$ concentration and 3 times faster $\mathrm{OH}$ oxidation rate in E1a than in E1c as shown in Table 1 and Fig. 5 and will be discussed further in Sect. 3.2.3. In experiments with two ozone additions, the second ozone injection induced a very weak increase of aerosol number concentrations, but a large increase in aerosol volume concentrations.

\subsubsection{New particle formation from ozonolysis}

In experiment E3, 2-butanol was added to the chamber to remove the $\mathrm{OH}$. 2-butanol is known to scavenge the $\mathrm{OH}$ radicals efficiently thus ensuring that only ozonolysis reactions occur. Figure 4 shows the particle profiles of the ozonolysis experiment. Only a very weak nucleation event was observed in this experiment. The maximum number concentration was only 8120 particle $\mathrm{cm}^{-3}$, much lower than that was found during $\mathrm{OH}+\mathrm{O}_{3}$ initiated cases. On the other hand, a relatively high rate of increase in aerosol volume was observed.

\subsubsection{Particle formation and growth rates}

The experiments described here emphasize the variability in new particle formation when different oxidants initiate reaction. The roles of $\mathrm{OH}-$ and $\mathrm{O}_{3}$-induced oxidation in new particle formation can be interpreted using the results from our kinetic model. The particle formation rates (see Sect. 2.4) and condensational diameter growth rates along with the oxidation reaction rates of monoterpenes with $\mathrm{OH}$ and $\mathrm{O}_{3}$ are shown in Fig. 5 and Table 4. Intensive particle formation usually ended at the initial stages of reaction in this study (less than $60 \mathrm{~min}$ after the beginning of experiment) and growth continued as long as VOCs and $\mathrm{O}_{3}$ were available. In E1a, very fast aerosol formation, with rate as high as $360 \mathrm{~cm}^{-3} \mathrm{~s}^{-1}$, was observed, 

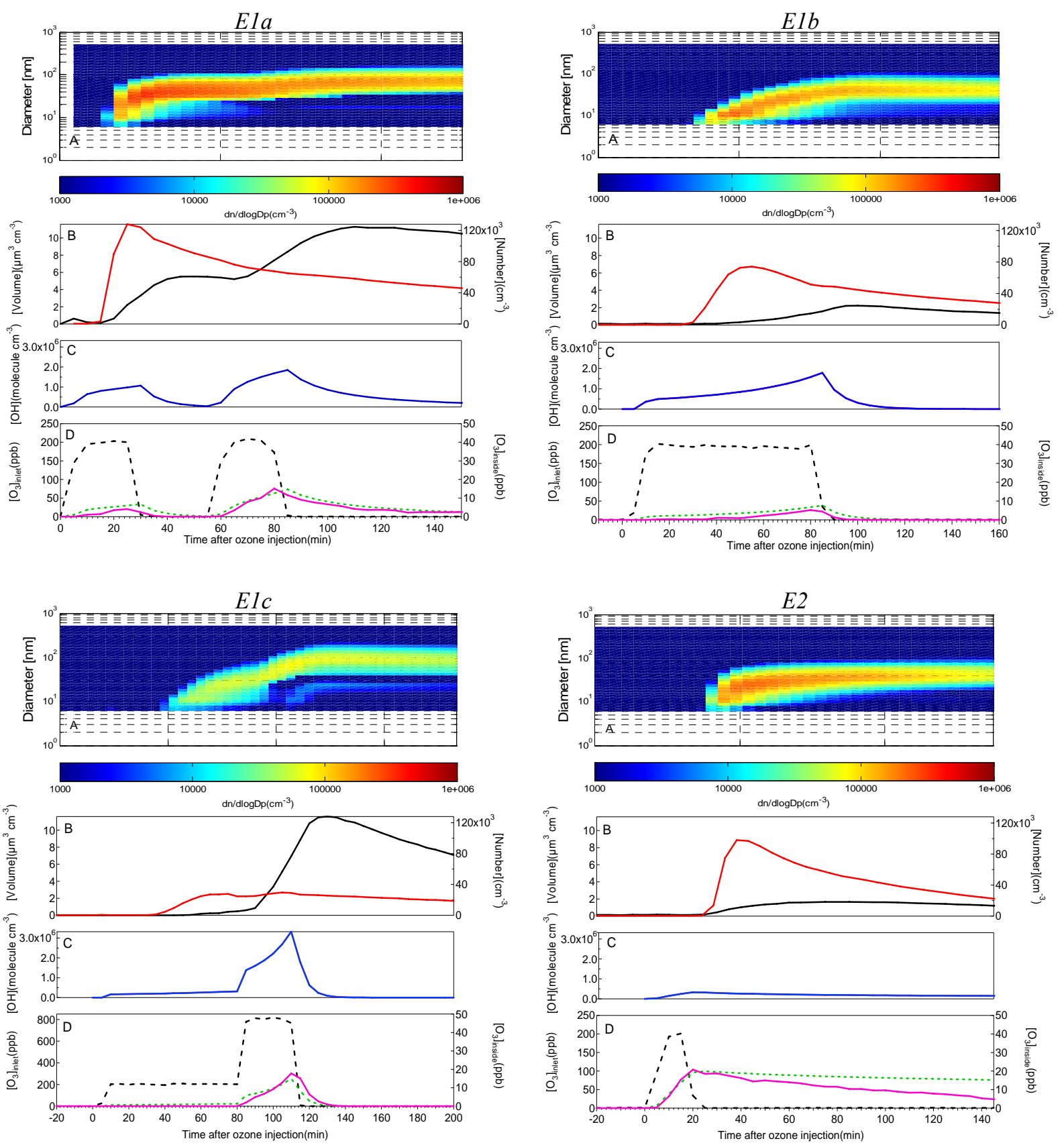

Fig. 3. New particle formation from $\mathrm{OH}$ - and $\mathrm{O}_{3}$-initiated oxidations of pine emissions. The frames contain, from top to bottom: (a) particles size distribution intensity plot, (b) measured aerosol number concentration (red curve) and volume concentration (black curve), (c) modeled $\mathrm{OH}$ concentration inside the chamber (blue curve), and (d) measured ozone concentrations at the inlet (black dashed curve) and inside the chamber (pink curve) and modeled ozone concentration inside the chamber (green dashed curve).

consistent with the rapid $\mathrm{OH}$ oxidation rate (as defined in Sect. 2.6) of $140 \times 10^{6}$ molecules $\mathrm{cm}^{-3} \mathrm{~s}^{-1}$ calculated with the model. In the pure ozonolysis experiment (E3, with $\mathrm{OH}$ scavenger present), the formation rate was quite low $\left(<0.5 \mathrm{~cm}^{-3} \mathrm{~s}^{-1}\right)$. In this case, $\mathrm{OH}$ oxidation rate is also low $\left(0.72 \times 10^{6}\right.$ molecules $\left.\mathrm{cm}^{-3} \mathrm{~s}^{-1}\right)$, though the $\mathrm{O}_{3}$ oxidation rate was quite high $\left(49.4 \times 10^{6}\right.$ molecules $\left.\mathrm{cm}^{-3} \mathrm{~s}^{-1}\right)$. These results indicate that $\mathrm{OH}$-initiated oxidation reactions play a very important role in nucleation and the early stages of particle growth, whereas the ozonolysis of monoterpenes is less effectively involved in these processes under the current experimental conditions. Once the new particles are formed, $\mathrm{OH}$ oxidation reactions appear to have a weak influence on aerosol formation during the second ozone addition period 

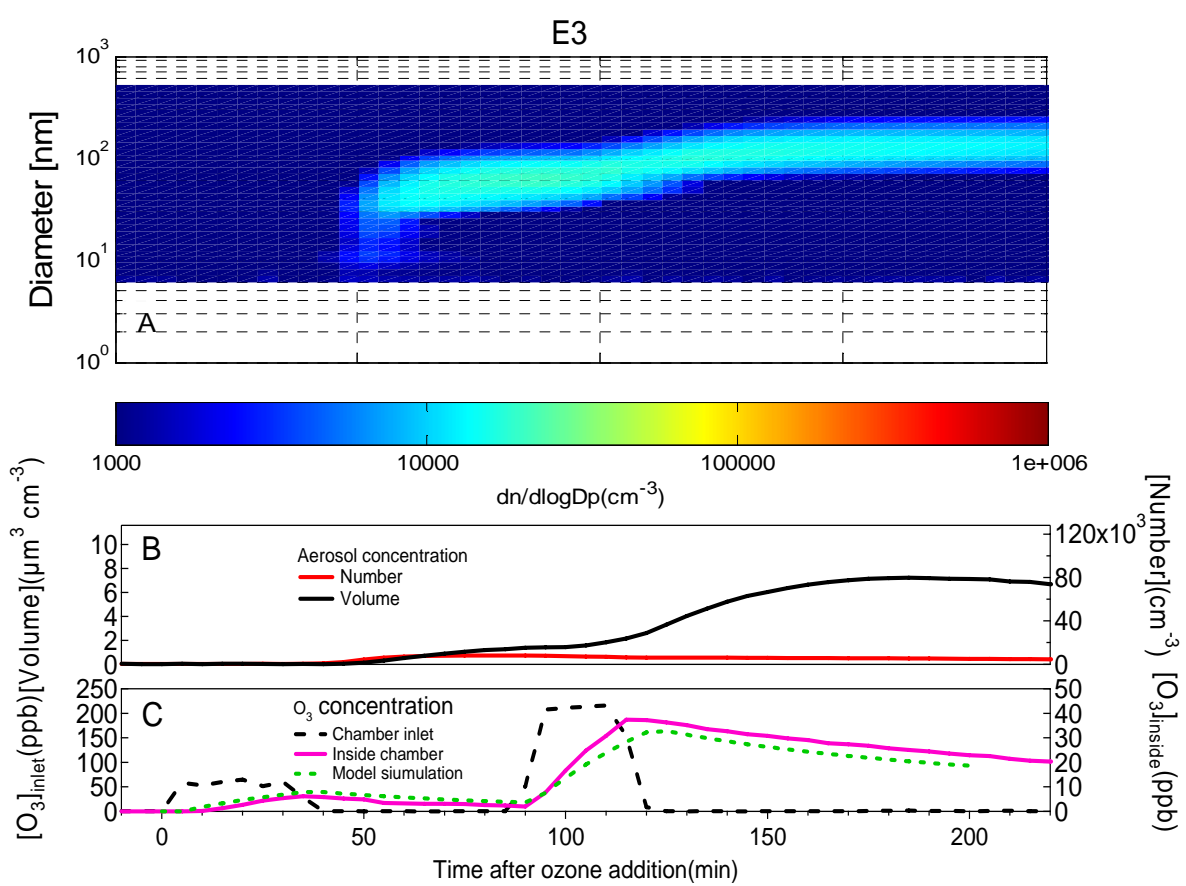

Fig. 4. New particle formation from ozonolysis of pine emissions in the presence of 2-butanol OH scavenger. The panel legends are the same as in Fig. 3. Modeled $\mathrm{OH}$ concentration was quite low and is not shown.
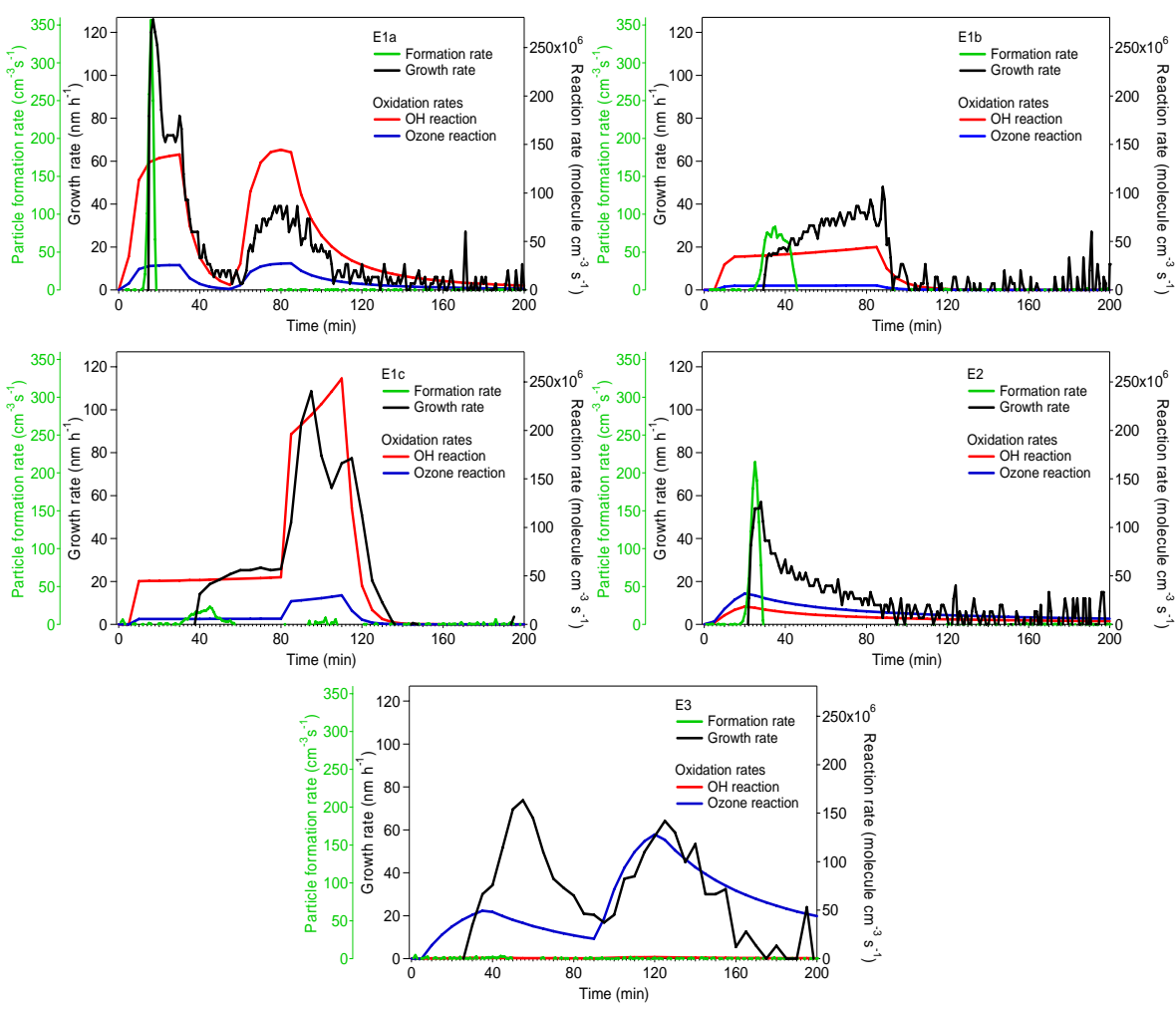

Fig. 5. Effects of ozone- and OH-initiated oxidation rates with emitted VOCs on new particle formation and growth rates. In these panels,

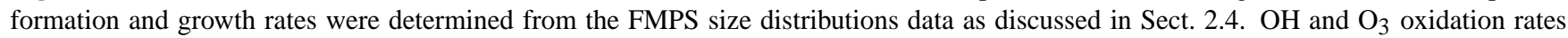
were calculated using the model described in Sect. 2.6. 


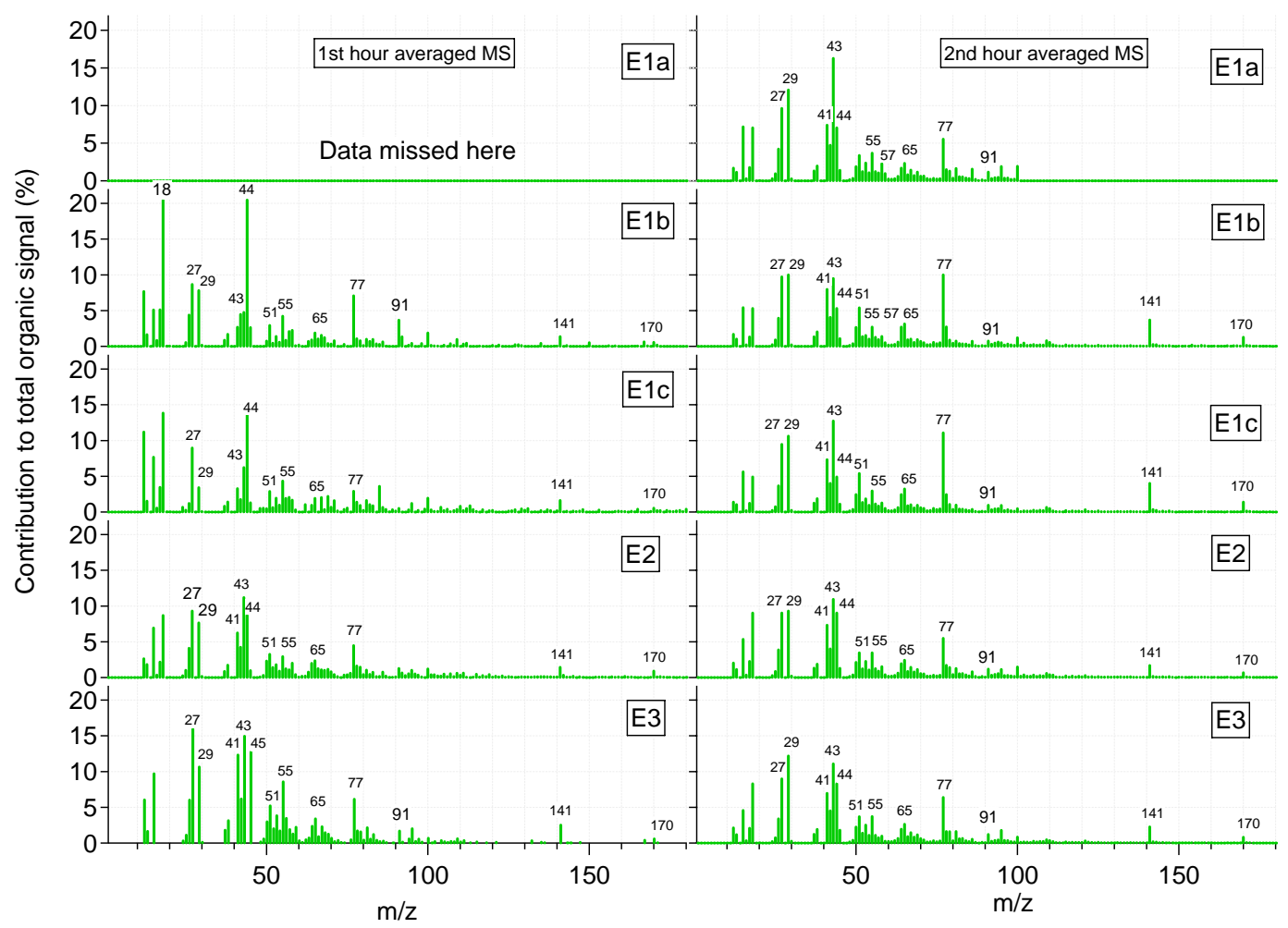

Fig. 6. Mass spectra of the aerosol products of the oxidation of pine VOCs from the first two hours of each experiment. All mass spectra are normalized to the sum total of all organic mass fragments, providing a quantitative fractional contribution of each mass fragment to the total measured signal. The left and right panels correspond to the mass spectra of the first and the second hours of reactions, respectively. In E1a, AMS scanned in the range of 1-100 amu, whereas the other four experiments scanned a wider range (1-200 amu), leading to small difference in percentage contributions in E1a. No AMS measurements were made in the first hour of experiment of E1a.

(second $\mathrm{OH}$ concentration peak, shown for E1a and E1c in Fig. 5), instead participating in the condensational growth process. This can be explained by the importance of reaching a high supersaturation in order for strong nucleation and early particle growth to occur. Such conditions are possible in the beginning of the experiment when there are no particles present in the chamber, i.e. there is no surface onto which vapor may condense. At the second $\mathrm{OH}$ peak, total particulate surface area in the chamber is high, and the reaction products will start condensing to existing aerosol as soon as they reached supersaturation. High supersaturations are therefore not possible leading to only weak (or no) new particle formation.

The modeled $\mathrm{OH}$ and $\mathrm{O}_{3}$ reaction rates also show correlations with the condensational growth rates in the experiments. The peak growth rate in E1a $\left(126 \mathrm{~nm} \mathrm{~h}^{-1}\right)$ is 1.7 times higher than that of $\mathrm{E} 3$ even though its $\mathrm{O}_{3}$ reaction rate $\left(25.5 \times 10^{6}\right.$ molecules $\left.\mathrm{cm}^{-3} \mathrm{~s}^{-1}\right)$ is two-times lower. Similarly, an $\mathrm{O}_{3}$ reaction rate of $5.5 \times 10^{6}$ molecules $\mathrm{cm}^{-3} \mathrm{~s}^{-1}$ was observed in E1c, which is 9 times lower than in E3. However, a growth rate of $25.0 \mathrm{~nm} \mathrm{~h}^{-1}$ in E1c was observed, which is only 3 times lower than in E3. These results indicate that not only $\mathrm{OH}$ but also $\mathrm{O}_{3}$ play roles in the aerosol condensational growth process. In $\mathrm{E} 3$, the $\mathrm{OH}$ reaction rate is at least 25 times lower $\left(0.72 \times 10^{6}\right.$ molecules $\left.\mathrm{cm}^{-3} \mathrm{~s}^{-1}\right)$ than the other four cases $\left(>18.3 \times 10^{6}\right.$ molecules $\left.\mathrm{cm}^{-3} \mathrm{~s}^{-1}\right)$. However, a high growth rate of $73.8 \mathrm{~nm} \mathrm{~h}^{-1}$ was achieved, suggesting that the ozonolysis of VOCs is more efficient that $\mathrm{OH}$ oxidation for aerosol growth.

Comparison between experiments E1a and E1b (Table 4) further verifies the above conclusions. These experiments were selected because their initial emission distributions were roughly the same. The initial emitted VOCs distributions were found to have an influence on the nucleation and growth rates as discussed below. The particle formation rate in E1a was 4.5 times higher than that in E1b, which is consistent with 3.8 times faster of $\mathrm{OH}$ oxidation rates in E1a than in E1b. Similarly, a $126.0 \mathrm{~nm} \mathrm{~h}^{-1}$ diameter growth rate in E1a was observed, 6.6 times higher than that in E1b, which corresponds well to the $\mathrm{O}_{3}$ oxidation rates in E1a of 6.3 times faster than in E1b.

Aerosol formation and growth rates were also impacted by the amounts and molecular structures of emitted VOCs. Oxidation of compounds with different positions of unsaturated bonds and number of carbon atoms in the molecules can result in different aerosol growth rates and SOA mass yields (Griffin et al., 1999; $\mathrm{Ng}$ et al., 2006). Since $\Delta^{3}$-carene compound has one endo double bond (internal to ring structure) 
Table 4. Comparisons of particle formation and growth rates vs. $\mathrm{OH}$ and $\mathrm{O}_{3}$ oxidation rates.

\begin{tabular}{lllll}
\hline $\begin{array}{l}\text { Exp. } \\
\text { No. }\end{array}$ & $\begin{array}{l}\text { Particle formation rate } \\
\left(\mathrm{cm}^{-3} \mathrm{~s}^{-1}\right)\end{array}$ & $\begin{array}{l}\text { OH oxidation rate } \\
\left(\times 10^{7} \text { molecule } \mathrm{cm}^{-3} \mathrm{~s}^{-1}\right)\end{array}$ & $\begin{array}{l}\text { Growth rate } \\
\left(\mathrm{nm} \mathrm{h}^{-1}\right)\end{array}$ & $\begin{array}{l}\mathrm{O}_{3} \text { oxidation rate } \\
\left(\times 10^{7}, \text { molecule } \mathrm{cm}^{-3} \mathrm{~s}^{-1}\right)\end{array}$ \\
\hline E1a & 360.0 & 14 & 126.0 & 2.5 \\
E1b & 80.0 & 3.7 & 19.0 & 0.4 \\
\hline
\end{tabular}

Table 5. Fraction by which each VOC reacts with $\mathrm{OH}$ during the first hour of new particle formation.

\begin{tabular}{|c|c|c|c|c|c|c|c|c|c|c|}
\hline $\begin{array}{l}\text { Fraction } \\
(\mathrm{VOC}+\mathrm{OH}, \%)\end{array}$ & $\alpha$-pinene & $\beta$-pinene & $\Delta^{3}$-carene & limonene & myrcene & camphene & sabinene & terpinolene & $\beta$-phellandrene & isoprene \\
\hline E1a & 81.3 & 97.2 & 94.3 & 84.5 & 76.2 & 99.8 & 90.8 & 45.3 & 96.2 & 98.2 \\
\hline E1b & 86.1 & 98.0 & 95.9 & 88.6 & 81.9 & 99.8 & 93.3 & 54.0 & 97.3 & 98.7 \\
\hline E1c & 85.8 & 98.0 & I & 88.3 & 81.6 & 99.8 & I & I & 97.2 & 98.7 \\
\hline E2 & 32.5 & 79.3 & 64.8 & 73.5 & 26.2 & 97.8 & 52.2 & 8.4 & 37.7 & 85.9 \\
\hline E3 & 1.2 & 8.7 & I & 1.5 & 0.9 & 52.8 & I & I & 6.5 & 13.2 \\
\hline
\end{tabular}

and is more likely to form condensable products than compounds with external double bonds (Griffin et al., 1999), the absence of $\Delta^{3}$-carene compound in the E1c and E3 might contribute to the lower nucleation rates than other cases. Furthermore, the high contributions of $\beta$-pinene (with an exo double bond) to the total VOC mix in E1c might lead to the lower nucleation rate. The conclusion that $\beta$-pinene may have inhibited particle formation in the Holm oak (Quercus ilex) experiments was also reached in previous work (VanReken et al. 2006).

Nucleation and growth from the oxidation of monoterpenes by $\mathrm{OH}$ and $\mathrm{O}_{3}$ has been studied over the past ten years (Bonn and Moortgat, 2002; Burkholder et al., 2007; Hoppel et al., 2001; Griffin et al., 1999; Mentel et al., 2009). Most studies were performed using one monoterpene such as $\alpha$-pinene and $\beta$-pinene as representative compounds to assess the $\mathrm{OH}-$ and $\mathrm{O}_{3}$-initiated oxidation on new particle formation efficiency. Bonn and Moortgat used a scanning mobility particle sizer (SMPS) to study the new particle formation during the oxidation of $\alpha$ - and $\beta$-pinene by $\mathrm{O}_{3}$ and $\mathrm{OH}$. By comparing the aerosol number and volume concentrations in different cases, they reported that ozonolysis of monoterpenes was much more efficient for particle formation than what was the observed for $\mathrm{OH}$-initiated case. This contradicts our results in which ozonolysis is less effective in nucleation process. Our results are consistent with the results of Burkholder et al. (2007), which find that monoterpene ozonolysis alone (with no $\mathrm{OH}$ radical reaction) cannot yield significant particle formation. However, we find that ozonolysis does contribute to particle growth. The results of this study are in strong agreement with recent work showing that for the oxidation of pine emissions, ozonolysis does not induce particle formation and $\mathrm{OH}$ radicals are essential for new particle formation (Mentel et al., 2009).

\subsection{Chemical signatures}

Chemical signatures of the newly formed aerosols during the above experiments were investigated utilizing the AMS. Figure 6 displays the average mass spectra of SOA for the first hour and second hour for each experiment. All spectra were normalized to total mass signal. We can see that most of the spectra were characterized by some intense mass fragments at $m / z 27,29,41,43,44,51,55,65,77,91$ and 141. Mass Fragments 27, 29, 41, 43 and 55 represent the ion series of $\mathrm{C}_{n} \mathrm{H}_{2 n-1}^{+}$and $\mathrm{C}_{n} \mathrm{H}_{2 n+1}^{+}$and separated by 14 mass units due to loss of $\mathrm{CH}_{2}$, which can indicate the presence of heavily saturated and non-oxidized hydrocarbon-like organic species (Alfarra et al., 2006; Allan et al., 2006). Another potential contribution to mass 43 is an oxygen-containing fragment, $\mathrm{C}_{2} \mathrm{H}_{3} \mathrm{O}^{+}$. Fragment 44 corresponds to $\mathrm{CO}_{2}^{+}$, which represents highly oxidized classes of compounds containing carbonyl and carboxylic acid functional groups (Alfarra et al., 2006). The ion series $77\left(\mathrm{C}_{6} \mathrm{H}_{5}\right)$ and $91\left(\mathrm{C}_{7} \mathrm{H}_{7}\right)$ are usually considered to be associated with aromatic fragments (Zhang et al., 2005; Bahreini et al., 2005) but can be observed in this study. Mass fragments of 51 and 141 might be derived from the ozonolysis reaction of VOCs but their identifications are unclear at present.

In the TME experiments (E1b and E1c), mass spectra were dominated by mass fragment 44 , contributing to as high as $20.5 \%$ and $13.8 \%$ to the total first hour mass signal, respectively. As a comparison, during the $\mathrm{OH}$-scavenged experiment (left panel E3 in Fig. 6), no fractional contribution by $\mathrm{m} / \mathrm{z} 44$ signals was found in the first hour. This indicates $\mathrm{OH}$ plays a key role in forming species which fragment to give $m / z, 44$ species. The importance of $\mathrm{OH}$ reaction for each VOC (as a percentage of total reaction) during new particle formation is presented in Table 5. Values were calculated 


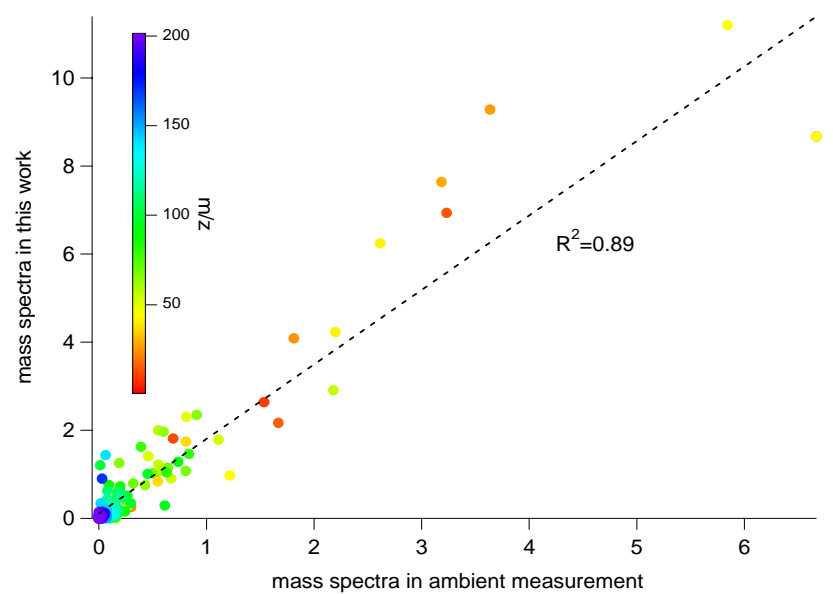

Fig. 7. Comparison of the AMS mass spectra of aerosol products in the chamber experiments from this work with those from ambient aerosol at Hyytiälä forest station. The plotted data are the fractional contribution of each mass peak to the total signal as shown in Fig. 6. The color scale is a function of $\mathrm{m} / \mathrm{z}$ number and the black dotted line is made by a linear fit. The mass spectrum in this work (y-axis) is the average from the first hour in E2 and ambient measurement is from two-hour averaged mass spectra during one nucleation event from 09:30 a.m. to 11:30 a.m. on 1 June 2007, in Hyytiälä forest in Finland.

from the following equation:

fraction $=\frac{\int_{0}^{t} r_{i, \mathrm{OH}(t)} d t}{\int_{0}^{t} r_{i, \mathrm{OH}(t)} d t+\int_{0}^{t} r_{i, \mathrm{O}_{3}(t)} d t}$

where $r_{i, \mathrm{OH}(t)}$ and $r_{i, \mathrm{O}_{3}(t)}$ were the reaction rates of $\mathrm{VOC}_{i}$ with $\mathrm{OH}$ and $\mathrm{O}_{3}$ at time $t(\mathrm{~min})$, respectively.

In all the OH-dominated experiments (E1a-1c), all VOCs but terpinolene reacted primarily $(>75 \%)$ with $\mathrm{OH}$ rather than $\mathrm{O}_{3}$. For $\mathrm{E} 2$, both $\mathrm{O}_{3}$ - and $\mathrm{OH}$-initiated oxidation were important, with the fraction of $\mathrm{OH}$ reaction varying from $8.4 \%$ (terpinolene) to $97.8 \%$ (myrcene). And in the ozonolysis experiment (E3), ozonolysis dominated for all VOC oxidation except camphene. The relative importance of $\mathrm{OH}$ reactions in all experiments corresponds well to the mass fraction of $m / z 44$ ions, strongly suggesting that $\mathrm{OH}$-initiated oxidation leads to the formation of highly oxidized aerosol species. On the other hand, the very high contribution of $\mathrm{m} / \mathrm{z}$ 43 signal to the mass loadings in E3 suggests that ozonolysis reaction might contribute more to the somewhat less oxidized products.

Averaged mass spectra appeared to have highly similar fragmentation patterns during the second hour, implying the products formed have broadly similar chemical functionality in these experiments. These similarities in the mass spectra were further confirmed in longer reaction time (not shown in Fig. 6), suggesting that once particles were formed, the chemical signature detected by AMS did not change significantly under these experimental conditions. However, there
Table 6. Effective density for different selected sizes of $\mathrm{OH}$ and $\mathrm{O}_{3}$ induced SOA.

\begin{tabular}{llll}
\hline $\begin{array}{l}\text { Chemical } \\
\text { Systems }\end{array}$ & $D m(\mathrm{~nm})$ & $D v a(\mathrm{~nm})$ & $\begin{array}{l}\text { Effective density } \\
\left(\mathrm{g} \mathrm{cm}^{-3}\right)\end{array}$ \\
\hline $\mathrm{OH}+\mathrm{O}_{3}$ & 76.1 & 101.8 & 1.34 \\
& 83.2 & 111.5 & 1.37 \\
reactions & 85.1 & 121.8 & 1.43 \\
& 104.2 & 133.7 & 1.28 \\
(E1to E2) & 111.4 & 150.3 & 1.35 \\
Average & & & $1.34 \pm 0.06$ \\
Ozonolysis & 112.6 & 153.4 & 1.36 \\
reactions & 128.2 & 176.1 & 1.37 \\
& 138.6 & 193.7 & 1.40 \\
(E3) & 155.9 & 212.4 & 1.36 \\
& 166.8 & 228.2 & 1.37 \\
Average & & & $1.38 \pm 0.03$ \\
\hline
\end{tabular}

are still significant differences in the minor mass fragments, suggesting that the aged SOA might have different chemical composition.

Contribution of $\mathrm{m} / \mathrm{z} 44$ to the mass spectrum in the second hour of oxidation decreased compared to the first hour in E1b (from $20.4 \%$ to $5.3 \%$ ) and E1c (13.8\% to $4.9 \%$ ). This might be due to the fact that terpenes react with $\mathrm{OH}$ and $\mathrm{O}_{3}$ in the first hour, leading to formation of the gas-phase nucleating and condensing species. The most highly oxidized material generally has the lowest vapor pressure, and therefore, condenses earlier. Once new particles are formed, less oxidized (more volatile) species may also partition into the aerosol phase, leading to an increase in aerosol volume and a decrease in oxygen content of the aerosol.

The mass spectra measured in the present studies also share some common features with those measured in the real atmosphere. The mass spectrum from particles following a nucleation event at Hyytiälä forest in Finland and Mexico city exhibit peaks at $\mathrm{m} / \mathrm{z} 27,29,41,43,44,51,55,57,77$, 91 and 141 (Alfarra et al., 2006; Allan et al., 2006; Salcedo et al., 2006). Comparison of the measurements made in this study with the average ambient mass spectrum from one nucleation event from 09:30 a.m. to 11:30 a.m. on 1 June 2007 at Hyytiälä is shown in Fig. 7. The similarities $\left(R^{2}=0.89\right)$ in these two types of mass spectra indicate that the experimental results are able to reproduce the product distributions of SOA formed in the real atmosphere.

\subsection{Effective density (ED)}

Effective density of SOA was calculated following the approach outlined in Sect. 2.5. In this method, the mobility and vacuum aerodynamic diameters were identified from the peak values by using a log-normal fitting to volume/mass size distributions. Table 6 lists parts of selected particle mobility diameters, the measured aerodynamic diameters and 
the corresponding effective density after the initial growth of particles.

The determined effective density from the $\mathrm{OH}$ and $\mathrm{O}_{3}$ oxidation induced SOA was $1.34 \pm 0.06 \mathrm{~g} \mathrm{~cm}^{-3}$, nearly identical to the value of $1.38 \pm 0.03 \mathrm{~g} \mathrm{~cm}^{-3}$ of particles from the ozonolysis reaction systems. The results show that the effective density for both types of SOA is not substantially impacted by the initiating oxidants. The density is also found to be independent of particle size within the accumulation mode. However the effective density showed a dependence on the particle size with Aitken mode in this work and these results need further confirmation. Our reported aerosol densities are in agreement with measured densities of $1.25 \pm 0.15 \mathrm{~g} \mathrm{~cm}^{-3}$ of SOAs from real pine emissions (Mentel et al., 2009). These results are also consistent with density measurements of $1.2-1.7 \mathrm{~g} \mathrm{~cm}^{-3}$ for ambient aerosol and laboratory-generated monoterpene SOA (Shilling et al., 2009; Saathoff et al., 2008; Bahreini et al., 2005; Alfarra et al., 2006; Kostenidou et al., 2007; Kannosto et al., 2008).

Accurate measurements of density are very important to convert the aerosol volume concentration to mass loadings. The effective density is heavily affected by the actual material density and particle shape factor (Bahreini et al., 2005; DeCarlo et al., 2004). Alfarra et al. (2006) reported shape of SOA formed from the photooxidation of $\alpha$-pinene to be spherical. In their experiments, effective densities were equivalent to the material densities. However, SOA are reported to be in solid or waxy phase with densities larger than $1.25 \mathrm{~g} \mathrm{~cm}^{-3}$ from the ozonolysis of biogenic emissions (Kostenidou et al., 2007). Irregular shapes of the solid or waxy aerosol make the effective density lower than the real material density. In this study, our aerosol might be nonspherical and our ongoing biogenic SOA experiments are investigating this possibility. This will be further discussed in future work.

\section{Conclusions}

We have studied freshly formed aerosols following the gas phase oxidation of the direct emissions of Scots pine (Pinus sylvestris L.) seedlings in a smog chamber. New particle formation events following ozonolysis and $\mathrm{O}_{3}$ plus $\mathrm{OH}$ initiated oxidation were characterized. 2-butanol and TME were used to control the ratios and the amount of $\mathrm{O}_{3}$ and $\mathrm{OH}$. Emitted gaseous species, aerosol formation, aerosol condensational growth, aerosol chemical composition and aerosol density are measured and investigated in this study using GC-MS, PTR-MS, FMPS, AMS and a chemical kinetics model.

Major emitted VOCs from Scots pine are observed to be monoterpenes. Ozone- and $\mathrm{OH}$-initiated oxidation of these VOCs produced large amounts of new particles. $\mathrm{OH}$-initiated oxidation plays a critical role during the initial stages of nucleation and new particle formation. Ozonolysis seems to be more important for the particle condensational growth, but it does not contribute substantially to particle formation. These results demonstrate that the $\mathrm{OH}$ oxidation of VOCs could be a source of new organic particles in the atmosphere.

Mass spectral results show that highly oxidized compounds ( $\mathrm{m} / \mathrm{z} 44$ signals) contribute more to SOA formed from $\mathrm{OH}$-initiated oxidation of emitted VOCs during the initial stage of nucleation events. Ozonolysis of emitted VOCs produces SOA which is less oxidized, with the mass spectrum dominated by the $m / z, 43$ ions. Overall, the mass spectral patterns in different experiments do not differ significantly, indicating the SOA produced have broadly similar chemical functionality.

From AMS and FMPS data it was determined that the aerosol effective densities are almost identical in these two oxidation systems, implying that the products formed by the different oxidants have roughly similar densities.

The experiments carried out here were designed to closely match atmospheric conditions as much as possible, so that the present results would be applicable to new particle formation and growth in the atmosphere, particularly in pristine forested environments. The oxidants $\left(\mathrm{O}_{3}\right.$ and $\left.\mathrm{OH}\right)$ and organics (monoterpenes) studied are among the most important in the troposphere; concentrations of $\mathrm{OH}$ and monoterpenes approached tropospheric levels; and the organics included an atmospherically relevant mixture of monoterpenes (direct vegetation emissions).

Acknowledgements. This work was funded by the Academy of Finland (decision no. 120802, 111543, 123466 and Centre of Excellence Programme). JS acknowledges the financial support of the Saastamoinen foundation and the Office of Science (BER), U.S. Department of Energy, grant DE-FG-02-05ER63997. We thank the staff at the Kuopio University Research Garden for maintaining the plants.

Edited by: G. McFiggans

\section{References}

Alfarra, M. R., Paulsen, D., Gysel, M., Garforth, A. A., Dommen, J., Prévôt, A. S. H., Worsnop, D. R., Baltensperger, U., and Coe, H.: A mass spectrometric study of secondary organic aerosols formed from the photooxidation of anthropogenic and biogenic precursors in a reaction chamber, Atmos. Chem. Phys., 6, 52795293, 2006,

http://www.atmos-chem-phys.net/6/5279/2006/.

Allan, J. D., Alfarra, M. R., Bower, K. N., Coe, H., Jayne, J. T., Worsnop, D. R., Aalto, P. P., Kulmala, M., Hyötyläinen, T., Cavalli, F., and Laaksonen, A.: Size and composition measurements of background aerosol and new particle growth in a Finnish forest during QUEST 2 using an Aerodyne Aerosol Mass Spectrometer, Atmos. Chem. Phys., 6, 315-327, 2006, http://www.atmos-chem-phys.net/6/315/2006/.

Allan, J. D., Delia, A. E., Coe, H., Bower, K. N., Alfarra, M. R., Jimenez, J. L., Middlebrook, A. M., Drewnick, F., Onasch, T. B., Canagaratna, M. R., Jayne, J. T., and Worsnop, D. R.: A generated method for the extraction of chemically resolved mass spectra from aerodyne aerosol mass spectrometer data, J. Aerosol Sci., 35, 902-922, 2004. 
Allan, J. D., Jimenez, J. L., Williams, P. I., Alfarra, M. R., Bower, K. N., Jayne, J. T., Coe, H., and Worsnop, D. R.: Quantitative sampling using an Aerodyne aerosol mass spectrometer 1. Techniques of data interpretation and error analysis, J. Geophys. Res., 108, 4090, doi:10.1029/2002JD002358, 2003.

Aschmann, S. M., Arey, J., and Atkinson, R.: OH radical formation from the gas-phase reactions of $\mathrm{O}_{3}$ with a series of terpenes, Atmos. Environ., 36, 4347-4355, 2002.

Atkinson, R. and Arey, J.: Atmospheric degradation of volatile organic compounds, Chem. Rev., 103, 4605-4638, 2003 a.

Atkinson, R., and Arey, J.: Gas-phase tropospheric chemistry of biogenic volatile organic compounds: a review, Atmos. Environ., 37, S197-S219, 2003b.

Bahreini, R., Keywood, M. D., Ng, N. L., Varutbangkul, V., Gao, S., Flagan, R. C., Seinfeld, J. H., Worsnop, D. R., and Jimenez, J. L.: Measurements of secondary organic aerosol from oxidation cycloalkenes, terpenes, and $\mathrm{m}$-Xylene using an Aerodyne Aerosol Mass Spectrometer, Environ. Sci. Technol., 39, 56745688, 2005.

Berndt, T., Böge, O., and Stratmann, F.: Atmospheric particle formation from the ozonolysis of alkenes in the presence of $\mathrm{SO}_{2}$, Atmos. Environ., 38, 2145-2153, 2004.

Bonn, B. and Moortgat, G. T.: New particle formation during $\alpha$ and $\beta$-pinene oxidation by $\mathrm{O}_{3}, \mathrm{OH}$ and $\mathrm{NO}_{3}$, and the influence of water vapour: particle size distribution studies, Atmos. Chem. Phys., 2, 183-196, 2002, http://www.atmos-chem-phys.net/2/183/2002/.

Burkholder, J. B., Baynard, T., Ravishankara, A. R., and Lovejoy, E. R.: Particle nucleation following the $\mathrm{O}_{3}$ and $\mathrm{OH}$ initiated oxidation of $\alpha$-pinene and $\beta$-pinene between 278 and $320 \mathrm{~K}$, J. Geophys. Res., 112, D10216, doi:10.1029/2006JD007783, 2007.

Claeys, M., Graham, B.,Vas, G., Wang, W., Vermeylen, R.,Pashynska, V., Cafmeyer, J., Guyon, P.,Andreae, M. O.,Artaxo, P., and Maenhaut, W.: Formation of secondary organic aerosols through photooxidation of isoprene, Science, 303, 1173-1176, 2004.

Dal Maso, M., Kulmala, M., Riipinen, I., Wagner, R., Hussein, T., Aalto, P. P., and Lehtinen, E. J.: Formation and growth of fresh atmospheric aerosols: eight years of aerosol size distribution data from SMEAR II, Hyytiälä, Finland, Boreal Environ. Res., 10, 323-336, 2005.

DeCarlo, P. F., Slowik, J. G., Worsnop, D. R., Davidovits, P., and Jimenez, J. L.: Particle morphology and density characterization by combined mobility and aerodynamic diameter measurements. Part 1: Theory, Aerosol Sci. Tech., 38, 1185-1205, 2004.

de Gouw, J. and Warneke, C.: Measurements of volatile organic compounds in the earths atmosphere using proton-transferreaction mass spectrometry, Mass Spec. Rev., 26, 223-257, 2007.

Docherty, K. S. and Ziemann, P. J.: Effects of stabilized Criegee Intermediate and $\mathrm{OH}$ radical scavengers on aerosol formation from reactions of $\beta$-Pinene with $\mathrm{O}_{3}$, Aerosol Sci. Tech., 37, 877-891, 2003.

Gao, S., Keywood, M., Ng, N. L., Surratt, J., Varutbangkul, V., Bahreini, R., Flagan, R. C., and Seinfeld, J. H.: Low-MolecularWeight and oligomeric components in secondary organic aerosol from the ozonolysis of cycloalkenes and $\alpha$-Pinene, J. Phys. Chem. A, 108, 10 147-10 164, 2004.
Guenther, A., Hewitt, C. N., Erickson, D., Fall, R., Geron, C., Graedel, T., Harley, P., Klinger, L., Lerdau, M., Mckay, W. A., Pierce, T., Scholes, B., Steinbrecher, R., Tallamraju, R., Taylor, J., and Zimmerman, P.: A global-model of natural volatile organic-compound emissions, J. Geophys. Res., 100, 88738892, 1995.

Griffin, R. J., Cocker III, D. R., Flagan, R. C., and Seinfeld, J. H.: Organic aerosol formation from the oxidation of biogenic hydrocarbons, J. Geophys. Res., 104, 3555-3567, 1999.

Grosjean, E., DeAndrade, J. B., and Grosjean, D.: Carbonyl products of the gas-phase reaction of ozone with simple alkenes, Environ. Sci. Technol., 30, 975-983, 1996.

Guicherit R. and Roemer M.: Tropospheric ozone trends, Chemosphere-Global Change Science, 2, 167-183, 2000.

Hoffmann, T., Odum, J.R., Bowman, F., Collins, D., Klockow, D., Flagan, R., and Seinfeld, J. H.: Formation of organic aerosols from the oxidation of biogenic hydrocarbons, J. Atmos. Chem., 26, 189-222,1997.

Hoppel, W., Fitzgerald, J., Frick, G., Caffrey, P., Pasternack, L., Hegg, D., Gao, S., Leaitch, R., Shantz, N., Cantrell, C., Albrechcinski, T., Ambrusko, J., and Sullivan, W.: Particle formation and growth from ozonolysis of a-pinene, J. Geophy. Res., 106, 27 603-27 618, 2001.

Jayne, J. T., Leard, D. C., Zhang, X. F., Davidovits, P., Smith, K. A., Kolb, C. E., and Worsnop, D. R.: Development of an Aerosol Mass Spectrometer for size and composition analysis of submicron particles, Aerosol Sci. Tech., 33, 49-70, 2000.

Jang, M. and Kamens, R. M.: Newly characterized products and composition of secondary aerosols from the reaction of alphapinene with ozone, Atmos. Environ., 33, 459-474, 1999.

Jiménez, E., Lanza, B., Garzón, A., Ballesteros, B., and Albaladejo, J.: Atmospheric degradation of 2-Butanol, 2-Methyl-2-butanol, and 2, 3-Dimethyl-2-butanol: $\mathrm{OH}$ kinetics and UV absorption cross sections, J. Phys. Chem. A, 109, 10 903-10 909, 2005.

Jimenez, J. L., Jayne, J. T., Shi, Q., Kolb, C. E., Worsnop, D. R., Yourshaw, I., Seinfeld, J. H., Flagan, R. C., Zhang, X. F., Smith, K. A., Morris, J. W., and Davidovits, P.: Ambient aerosol sampling using the Aerodyne Aerosol Mass Spectrometer, J. Geophys. Res., 108, 8425, doi:10.1029/2001JD001213, $2003 \mathrm{a}$.

Jimenez, J. L., Bahreini, R., Cocker III, D. R., Zhuang, H., Varutbangkul, V., Flagan, R. C., Seinfeld, J. H., O’Dowd, C. D., and Hoffmann, T.: New particle formation from photooxidation of diiodomethane $\left(\mathrm{CH}_{2} \mathrm{I}_{2}\right)$, J. Geophys. Res., 108, 4318, doi:10.1029/2002JD002452, 2003b.

Joutsensaari, J., Loivamäki, M., Vuorinen, T., Miettinen, P., Nerg, A.-M., Holopainen, J. K., and Laaksonen, A.: Nanoparticle formation by ozonolysis of inducible plant volatiles, Atmos. Chem. Phys., 5, 1489-1495, 2005,

http://www.atmos-chem-phys.net/5/1489/2005/.

Kanakidou, M., Seinfeld, J. H., Pandis, S. N., Barnes, I., Dentener, F. J., Facchini, M. C., Van Dingenen, R., Ervens, B., Nenes, A., Nielsen, C. J., Swietlicki, E., Putaud, J. P., Balkanski, Y., Fuzzi, S., Horth, J., Moortgat, G. K., Winterhalter, R., Myhre, C. E. L., Tsigaridis, K., Vignati, E., Stephanou, E. G., and Wilson, J.: Organic aerosol and global climate modelling: a review, Atmos. Chem. Phys., 5, 1053-1123, 2005

Kannosto, J., Virtanen, A., Lemmetty, M., Mäkelä, J. M., Keskinen, J., Junninen, H., Hussein, T., Aalto, P., and Kulmala, M.: Mode resolved density of atmospheric aerosol particles, Atmos. Chem. 
Phys., 8, 5327-5337, 2008,

http://www.atmos-chem-phys.net/8/5327/2008/.

Kerminen, V.-M. and Kulmala, M.: Analytical formulae connecting the "real" and "apparent" nucleation rate and nuclei number concentration for atmospheric nucleation events, J. Aerosol Sci., 33, 609-622, 2002.

Keywood, M. D., Kroll, J. H., Varutbangkul, V., Bahreini, R., Flagan, R. C., and Seinfeld, J. H.: Secondary organic aerosol formation from cyclohexene ozonolysis: Effect of $\mathrm{OH}$ scavenger and the role of radical chemistry, Environ. Sci. Technol., 38, 33433350, 2004.

Kostenidou, E., Pathak, R. K., and Pandis, S. N.: An algorithm for the calculation of secondary organic aerosol density combining AMS and SMPS data, Aerosol Sci. Tech., 41, 1002-1010, 2007.

Koch, S., Winterhalter, R., Uherek, E., Kolloff, A., Neeb, P., and Moortgat, G. K.: Formation of new particles in the gas-phase ozonolysis of monoterpenes, Atmos. Environ., 34, 4031-4042, 2000.

Kroll, J. H., Ng, N. L., Murphy, S. M., Flagan, R. C., and Seinfeld, J. H.: Secondary organic aerosol formation from isoprene photooxidation, Environ. Sci. Technol., 40, 1869-1877, 2006.

Kulmala, M., Vehkamäki, H., Petäjä, T., Dal Maso, M., Lauria, A., Kerminen, V. -M., Birmili, W., and McMurry, P. H.: Formation and growth rates of ultrafine atmospheric particles: a review of observations, J. Aerosol Sci., 35, 143-176, 2004.

Laaksonen, A., Kulmala, M., O’Dowd, C. D., Joutsensaari, J., Vaattovaara, P., Mikkonen, S., Lehtinen, K. E. J., Sogacheva, L., Dal Maso, M., Aalto, P., Petäjä, T., Sogachev, A., Yoon, Y. J., Lihavainen, H., Nilsson, D., Facchini, M. C., Cavalli, F., Fuzzi, S., Hoffmann, T., Arnold, F., Hanke, M., Sellegri, K., Umann, B., Junkermann, W., Coe, H., Allan, J. D., Alfarra, M. R., Worsnop, D. R., Riekkola, M. -L., Hyötyläinen, T., and Viisanen, Y.: The role of VOC oxidation products in continental new particle formation, Atmos. Chem. Phys, 8, 2657-2665, 2008.

Lambe, A. T., Zhang, J. Y., Sage, A. M., and Donahue, N. M.: Controlled $\mathrm{OH}$ radical production via Ozone-alkene reactions for use in aerosol aging studies, Environ. Sci. Technol., 41, 23572363, 2007.

Lehtinen, K. E. J., Dal Maso, M., Kulmala, M., and Kerminen, V.M.: Estimating nucleation rates from apparent particle formation rates and vice versa: Revised formulation of the KerminenKulmala equation, J. Aerosol Sci., 38, 988-994, 2007.

Lindfors, V. and Laurila, T.: Biogenic volatile organic compound (VOC) emissions from forests in Finland, Boreal Environ. Res., 5, 95-113, 2000.

Lindinger, W., Hansel, A., and Jordan, A.: Proton-transfer-reaction mass spectrometry (PTR-MS): on-line monitoring of volatile organic compounds at pptv levels, Chem. Soc. Rev., 27, 347-354, 1998.

Logan, J. A.: Tropospheric ozone: Seasonal behavior, trends, and anthropogenic influence, J. Geophys. Res., 90, 25 553-25 585, 1985.

Manninen, A.-M., Vuorinen, M., and Holopainen, J. K.: Variation in growth, chemical defense and herbivore resistance in Scots pine provenances, J. Chem. Ecol., 24, 1315-1331, 1998.

Mäntylä. E., Alessio, G. A., Blande, J. D., Heijari, J., Holopainen, J. K., Laaksonen, T., Piirtola, P., and Klemola, T.: From plants to birds: Higher avian predation rates in trees responding to insect herbivory, PLoS ONE 3, e2832, 2008.
McFiggans, G., Coe, H., Burgess, R., Allan, J., Cubison, M., Alfara,M. R., Saunders, R., Saiz-Lopez, A.,Plane, J. M. C., Wevill, D., Carpenter, L., Rickard, A. R., and Monks, P. S.: Direct evidence for coastal iodine particles from Laminaria macroalgaelinkage to emissions of molecular iodine, Atmos. Chem. Phys., 4, 701-713, 2004,

http://www.atmos-chem-phys.net/4/701/2004/.

McMurry, P. H., Fink, M., Sakurai, H., Stolzenburg, M. R., Mauldin, R. L., Smith, J., Eisele, F., Moore, K., Sjostedt, S., Tanner, D., Huey, L. G., Nowak, J. B., Edgerton, E., Voisin, D.: A criterion for new particle formation in the sulfur-rich Atlanta atmosphere, J. Geophys. Res., 110, D22S02, doi:10.1029/2005JD005901, 2005.

Mentel, Th.F., Wildt, J., Kiendler-Scharr, A., Kleist, E., Tillmann, R., Dal Maso, M., Fisseha, R., Hohaus, Th., Spahn, H., Uerlings, R., Wegener, R., Griffiths, P.T., Dinar, E., Rudich, Y., and Wahner, A.: Photochemical production of aerosols from real plant emissions, Atmos. Chem. Phys., 9, 4387-4406, 2009,

http://www.atmos-chem-phys.net/9/4387/2009/.

Ng, N. L., Chhabra, P. S., Chan, A. W. H., Surratt, J. D., Kroll, J. H., Kwan, A. J., McCabe, D. C., Wennberg, P. O., Sorooshian, A., Murphy, S. M., Dalleska, N. F., Flagan, R. C., and Seinfeld, J. H.: Effect of $\mathrm{NO}_{x}$ level on secondary organic aerosol (SOA) formation from the photooxidation of terpenes, Atmos. Chem. Phys., 7, 5159-5174, 2007,

http://www.atmos-chem-phys.net/7/5159/2007/.

Ng, N. L., Kroll, J. H., Keywood, M. D., Bahreini, R., Varutbangkul, V., Flagan, R. C., and Seinfeld, J. H.: Contribution of first- versus second-generation products to secondary organic aerosols formed in the oxidation of biogenic hydrocarbons, Environ. Sci. Technol., 40, 2283-2297, 2006.

Niki, H., Maker, P. D., Savage, C. M., Breitenbach, L. P., and Hurley, M. D.: FTIR spectroscopic study of the mechanism for the gas-phase reaction between ozone and tetramethylethylene, J. Phys. Chem., 91, 941-946, 1987.

Odum, J. R., Hoffmann, T., Bowman, F., Collins, D., Flagan, R. C., and Seinfeld, J. H.: Gas/Particle partitioning and secondary organic aerosol yields, Environ. Sci. Technol., 30, 2580-2585, 1996.

Paulson, S. E., Sen, A. D., Liu, P., Fenske, J. D., and Fox, M. J.: Evidence of formation of $\mathrm{OH}$ radicals from the reaction of $\mathrm{O}_{3}$ with alkenes in the gas phase, Geophy. Res. Lett., 24, 3193-3196, 1997.

Petäjä, T., Mauldin III, R. L., Kosciuch, E., McGrath, J., Nieminen, T., Boy, M., Adamov, A., Kotiaho, T., and Kulmala, M.: Sulfuric acid and $\mathrm{OH}$ concentrations in a boreal forest site, Atmos. Chem. Phys., 9, 7435-7448, 2009,

http://www.atmos-chem-phys.net/9/7435/2009/.

Pinto, D. M., Tiiva, P., Miettinen, P., Joutsensaari, J., Kokkola, H., Nerg, A-M., Laaksonen, A., and Holopainen, J. K.: The effects of increasing atmospheric ozone on biogenic monoterpene profiles and the formation of secondary aerosols, Atmos. Environ., 41, 4877-4887, 2007.

Presto, A. A. and Donahue, N. M.: Secondary organic aerosol production from terpene ozonolysis. 2. Effect of NOx concentration, Environ. Sci. Technol., 39, 7046-7054, 2005.

Räisänen, T., Ryyppö, A., and Kellomäki, S.: Effects of elevated $\mathrm{CO}_{2}$ and temperature on monoterpene emission of Scots pine (Pinus sylvestris L.), Atmos. Environ., 42, 4160-4171, 2008. 
Saathoff, H., Naumann, K.-H., Möhler, O., Jonsson, Å. M., Hallquist, M., Kiendler-Scharr, A., Mentel, Th. F., Tillmann, R., and Schurath, U.: Temperature dependence of yields of secondary organic aerosols from the ozonolysis of $\alpha$-pinene and limonene, Atmos. Chem. Phys., 9, 1551-1577, 2009,

http://www.atmos-chem-phys.net/9/1551/2009/.

Sakulyanontvittaya, T., Duhl, T., Wiedinmyer, C., Helmig, D., Matsunaga, S., Potosnak, M., Milford, J., Guenther, A.: Monoterpene and sesquiterpene emission estimates for the United States, Environ. Sci. Technol., 42, 1623-1629, 2008.

Salcedo, D., Onasch, T. B., Dzepina, K., Canagaratna, M. R., Zhang, Q., Huffman, J. A., DeCarlo, P. F., Jayne, J. T., Mortimer, P., Worsnop, D. R., Kolb, C. E., Johnson, K. S., Zuberi, B., Marr, L. C., Volkamer, R., Molina, L. T., Molina, M. J., Cardenas, B., Bernabé, R. M., Márquez, C., Gaffney, J. S., Marley, N. A., Laskin, A., Shutthanandan, V., Xie, Y., Brune, W., Lesher, R., Shirley, T., and Jimenez, J. L.: Characterization of ambient aerosols in Mexico City during the MCMA-2003 campaign with Aerosol Mass Spectrometry: results from the CENICA Supersite, Atmos. Chem. Phys., 6, 925-946, 2006,

http://www.atmos-chem-phys.net/6/925/2006/.

Shilling, J. E., Chen, Q., King, S. M., Rosenoern, T., Kroll, J. H., Worsnop, D. R., McKinney, K. A., and Martin, S. T.: Particle mass yield in secondary organic aerosol formed by the dark ozonolysis of $\alpha$-pinene, Atmos. Chem. Phys., 8, 2073-2088, 2008,

http://www.atmos-chem-phys.net/8/2073/2008/.

Shilling, J. E., Chen, Q., King, S. M., Rosenoern, T., Kroll, J. H., Worsnop, D. R., DeCarlo, P. F., Aiken, A. C., Surper, D., Jimenez, J. L., and Martin, S. T.: Loading-dependent elemental composition of $\alpha$-pinene SOA particles, Atmos. Chem. Phys., 9, 771-782, 2009, http://www.atmos-chem-phys.net/9/771/2009/.

Taipale, R., Ruuskanen, T. M., Rinne, J., Kajos, M. K., Hakola, H., Pohja, T., and Kulmala, M.: Technical Note: Quantitative long-term measurements of VOC concentrations by PTR-MS measurement, calibration, and volume mixing ratio calculation methods, Atmos. Chem. Phys., 8, 6681-6698, 2008,

http://www.atmos-chem-phys.net/8/6681/2008/.

Tarvainen, V., Hakola, H., Hellén, H., Bäck, J., Hari, P., and Kulmala, M.: Temperature and light dependence of the VOC emissions of Scots pine, Atmos. Chem. Phys., 5, 989-998, 2005, http://www.atmos-chem-phys.net/5/989/2005/.

Tsigaridis, K. and Kanakidou, M.: Global modeling of secondary organic aerosol in the troposphere: a sensitivity analysis, Atmos. Chem. Phys., 3, 1849-1869, 2003,

http://www.atmos-chem-phys.net/3/1849/2003/.
Tuazon, E. C., Aschmann, S., Arey, J., and Atkinson, R.: Products of the gas-phase reactions of $\mathrm{O}_{3}$ with a series methyl-substituted ethenes, Environ. Sci. Technol., 31, 3004-3009, 1997.

Tuazon, E. C., Aschmann, S, Arey, J., and Atkinson, R.: Products of the gas-phase reactions of a series of methyl-substituted ethenes with the $\mathrm{OH}$ radical, Environ. Sci. Technol., 32, 21062112, 1998.

Vaattovaara , P., Petäjä, T., Joutsensaari, J., Miettinen, P., Zaprudin, B., Kortelainen, A., Heijari, J., Yli-Pirilä, P., Aalto, P., Worsnop, D. R., and Laaksonen, A.: The evolution of nucleation- and Aitken-mode particle compositions in a boreal forest environment during clean and pollution-affected new-particle formation events, Boreal Environ. Res., 14, 662-682, 2009.

VanReken, T. M., Greenberg, J. P., Harley, P. C., Guenther A. B., and Smith, J. N.: Direct measurement of particle formation and growth from the oxidation of biogenic emissions, Atmos. Chem. Phys., 6, 4403-4413, 2006, http://www.atmos-chem-phys.net/6/4403/2006/.

Vuorinen, T., Nerg, A.-M., Ibrahim, M. A., Reddy, G. V. P., and Holopainen, J. K.: Emission of Plutella xylostella-induced compounds from cabbages grown at elevated $\mathrm{CO}_{2}$ and orientation behavior of the natural enemies, Plant Physiol., 135, 1984-1992, 2004.

Weber, R. J., Marti, J. J., McMurry, P. H., Eisele, F. L., Tanner, D. J., and Jefferson, A.: Measurements of new particle formation and ultrafine particle growth rates at a clean continental site, J. Geophys. Res., 102, 4375, doi: 10.1029/96JD03656, 1997.

Yu, J. Z., Cocker III, D. R., Griffin, R. J., Flagan, R. C., and Seinfeld, J. H.: Gas-phase ozone oxidation of monoterpenes: Gaseous and particulate products, J. Atmos. Chem., 34, 207-258, 1999.

Zhang, Q., Alfarra, M. R., Worsnop, D. R., Allan, J. D., Coe, H., Canagaratna, M. R. and Jimenez, J. L.: Deconvolution and quantification of hydrocarbon-like and oxygenated organic aerosols based on Aerosol Mass Spectrometry, Environ. Sci. Technol., 39, 4938-4952, 2005.

Zhang, Q., Stanier, C. O., Canagaratna, M. R., Jayne, J. T., Worsnop, D. R., Pandis, S. N., and Jimenez, J. L.: Insights into the chemistry of new particle formation and growth events in Pittsburgh based on Aerosol Mass Spectrometry, Environ. Sci. Technol., 38, 4797-4809, 2004.

Ziemann, P. J.: Formation of alkoxyhydroperoxy aldehydes and cyclic peroxyhemiacetals from reactions of cyclic alkenes with $\mathrm{O}_{3}$ in the presence of alcohols, J. Phys. Chem. A, 107, 20482060, 2003. 